\title{
Whither Notice PleAding?: PleAding PRACTICE IN THE DAYS BEFORE TWOMBLY
}

\author{
Jason A. Cantone*, Joe S. Cecil ${ }^{* *} \&$ Dhairya Jani ${ }^{* * *}$
}

\section{INTRODUCTION}

"Notice pleading is dead," stated Benjamin Spencer following the decision in Bell Atlantic Corp. v. Twombly. ${ }^{2}$ When testifying before the United States Senate Judiciary Committee, Stephen Burbank offered a eulogy for notice pleading and proposed an amendment to return pleading to the way it was the day before the Twombly decision. ${ }^{3}$ But what was the pleading practice the day before Twombly? What if, in the days before Twombly, pleading practice did not match the notice pleading standard as originally envisioned by the drafters of the Federal Rules of Civil Procedure ("the Federal Rules")? Legal and empirical scholars have extensively debated the potential effect of Twombly and Ashcroft v. Iqbal ${ }^{4}$ on motion practice and pleading standards. ${ }^{5}$ However, very little research addresses what pleading practice was like in the days before Twombly.

* J.D., Ph.D., M.A., University of Nebraska-Lincoln; B.S. University of Illinois at UrbanaChampaign. The views expressed herein are those of the authors and not necessarily those of the Federal Judicial Center. This manuscript was initially prepared for presentation at the 2013 Conference on Empirical Legal Studies (CELS). The authors would like to thank George Cort and Ashley Mason for their assistance in developing the databases, Keith Blackley and Patrick Sivertsen for their research assistance in developing the standards and for coding the complaints, Phillip Wininger for his assistance in assessing the length of the complaints, David Hoffman for his insightful research suggestions, and Richard Marcus and Edward Cooper for advice regarding amendments to the Federal Rules of Civil Procedure. We also wish to thank the commentators for our panel at the CELS conference for identifying areas that required elaboration. All errors herein are our own. Please address correspondence to jcantone @ fjc.gov.

** Ph.D., Northwestern University; J.D., Northwestern University; M.S. University of Oklahoma; B.S. University of Oklahoma. Dr. Cecil was the senior researcher on the project that led to this Article.

*** J.D., University of Pittsburgh School of Law; B.S. University of North Carolina at Chapel Hill. Mr. Jani was an extern for the Federal Judicial Center during the initial research and Study One of this Article.

1. A. Benjamin Spencer, Plausibility Pleading, 49 B.C. L. REV. 431, 431 (2008).

2. 550 U.S. 544 (2007).

3. Has the Supreme Court Limited Americans' Access to Courts?: Hearing Before the S. Comm. on the Judiciary, 111th Cong., app. A (2009) (prepared statement of Stephen B. Burbank, Professor for the Administration of Justice, University of Pennsylvania Law School), available at http://www.gpo.gov/fdsys/pkg/CHRG-111shrg56719/pdf/CHRG-111shrg56719.pdf.

4. 556 U.S. 662 (2009).

5. Commentators have argued that the Supreme Court's decisions in Twombly and Iqbal responded to growing concern over rising litigation costs, heavy case loads, and case management concerns. See 
In 1957, the Supreme Court, in Conley v. Gibson, ${ }^{6}$ supported a lenient interpretation of Rule 8 of the Federal Rules, which requires that a complaint must "give the defendant fair notice of what the plaintiff's claim is and the grounds upon which it rests" to survive a Rule 12(b)(6) motion to dismiss for failure to state a claim. ${ }^{7}$ Under Conley, "fair notice" required that a complaint be dismissed only if "it appears beyond doubt that the plaintiff can prove no set of facts in support of his claim ...." In 2009, however, Iqbal advanced the decision in Twombly by requiring parties to go beyond the Conley interpretation of "fair notice" and provide enough facts to meet a plausibility analysis, based in part on judges' personal experience and common sense. ${ }^{9}$ While the Supreme Court stated that the decisions in Twombly and Iqbal were not meant to support a heightened pleading standard, ${ }^{10}$ "there is close to a consensus among academic observers that the Iqbal/Twombly pleading standard marks a sharp break with the past"11 by shifting its long-standing support of notice pleading to the new plausibility pleading standard. Arthur Miller, reviewing changes in civil litigation, declared that Twombly and Iqbal 'represent a procedural 'sea change' in plaintiffs' ability to survive the pleading stage. [The Supreme Court] turn[s] their back on over sixty years of federal pleading jurisprudence as well as any possible alternative procedural approaches that might be better suited to meeting the concerns expressed in the Court's opinions." 12

The authors of this Article agree with Judge Ellis' statement that, "those who think that Iqbal and Twombly were mistakes would compound those mistakes to urge an immediate lurch back to Conley's "no set of facts" rule

generally Arthur R. Miller, From Conley to Twombly to Iqbal: A Double Play on the Federal Rules of Civil Procedure, 60 DuKE L.J. 1 (2010) (providing a thorough analysis of the potential reasoning behind the decisions in Twombly and Iqbal); see also Cristina Calvar, Note, "Twiqbal": A Political Tool, 37 J. LEGIS. 200 (2012). While at the time of Conley, between $11 \%$ and $12 \%$ of federal civil cases went to trial, less than $2 \%$ of cases terminated at or after trial at the time of Iqbal. See Burbank, supra note 3 , at 16 . However, trials in the past were simpler and could be tried more expeditiously than trials in the Twombly/Iqbal era. See Charles Clark, History, Systems and Functions of Pleading, 11 VA. L. REV. 517 (1925). For further discussion of empirical research, see Part III infra.

6. 355 U.S. 41 (1957).

7. Id. at 47 .

8. Id. at $45-46$.

9. Ashcroft v. Iqbal, 556 U.S. 662, 678 (2009).

10. Bell Atl. Corp. v. Twombly, 550 U.S. 544, 563 n.8 (2007); Iqbal, 556 U.S. at 677-78. For more discussion, see Part II infra.

11. Alexander A. Reinert, The Costs of Heightened Pleading, 86 IND. L.J. 119, 122-23 (2011). Reinert also provides a list of scholarly articles finding the change a "welcome" or "lamentable" one. Id. at n.16.

12. Arthur R. Miller, Simplified Pleading, Meaningful Days in Court, and Trials on the Merits: Reflections on the Deformation of Federal Procedure, 88 N.Y.U. L. REv. 286, 331 (2013). 
without first measuring the impact of the new pleading standard." ${ }^{13}$ It is important to address whether Twombly and Iqbal caused the shift from notice pleading practice to narrative pleading practice, pleading supported by sufficient facts to describe the context of the claims, or if narrative pleading practice predated those decisions. ${ }^{14}$ If narrative pleading was already commonplace before Twombly and Iqbal, those decisions likely had a more limited effect on pleading practice than some suggest.

This Article proceeds in five parts. Part II identifies the issue by tracing the history of pleading standards from the creation of the Federal Rules to the Twombly and Iqbal Supreme Court decisions to Congressional attempts to overturn the decisions. The lower courts did not strictly adhere to Conley before Twombly and Iqbal, and lower court decisions may have been representative of changes already taking place in the federal judiciary. Part III briefly addresses prior empirical research regarding potential changes due to Twombly and Iqbal. Part IV describes the role of the federal forms and presents the methodology of two studies. This Article examines initial pleading practice in automobile accident cases originally filed in federal court with federal defendants (Study 1) or with diversity jurisdiction (Study 2) to determine whether pleading practices pre-Twombly resembled notice pleading, or if such pleadings included additional facts not required by the standard. Automobile accident cases present a unique opportunity to examine how current pleading practices compare to the intent of the drafters of the Federal Rules. This intent is originally expressed in Form 11 (formerly Form 9), the illustrative complaint for a negligence action presented in the Appendix of Forms accompanying the Federal Rules. Part V discusses the findings, as well as the psychology of pleading, and offers some explanations as to why notice pleading practice was the exception, not the rule, the year before Twombly. Part VI concludes the Article.

Overall, our research indicates that complaints before Twombly often departed from notice pleading. The level of specificity of the factual allegations contained in the complaint far exceeded the liberal standard expressed in Conley and illustrated by Form 11. Pleading additional facts, beyond the notice pleading requirements in the Forms, was the dominant practice in simple negligence cases before Twombly. That is not to say that Twombly and Iqbal did not mark a change in the Supreme Court's

13. Hon. T.S. Ellis, III \& Nitin Shah, Iqbal, Twombly, and What Comes Next: A Suggested Empirical

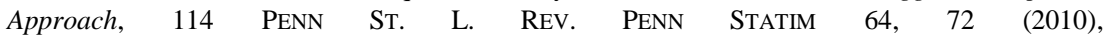
http://www.pennstatelawreview.org/114/114\%20Penn\%20Statim\%2064.pdf.

14. A good description of "narrative pleading" for our purposes is found in Swanson v. Citibank, N.A., 614 F.3d 400, 407 (7th Cir. 2010) (explaining that Twombly and Iqbal require "that the plaintiff must give enough details about the subject-matter of the case to present a story that holds together. In other words, the court will ask itself could these things have happened, not did they happen"). In our view, narrative pleading provides a narrative of facts that exceeds the requirements of a notice pleading standard. 
jurisprudence regarding pleading standards. ${ }^{15}$ Instead, as Brian Fitzpatrick stated, "Despite the Supreme Court's best efforts prior to Twombly, [] lower federal courts [were] using heightened pleading for some time." 16 Before Twombly, pleading practice already resembled narrative pleading and it should not be presumed that the fact-barren notice pleading of Form 11 (formerly Form 9) and Conley were "alive and well in spirit, even if not in every jot and tittle." 17 If the Supreme Court killed notice pleading, as has been suggested, it was only pulling the plug on a pleading practice that had already lost its vitality.

\section{PLEADING IN THE FEDERAL COURTS}

Twombly and Iqbal unleashed a wide array of legal analyses and initiatives, most of which advocated for a return to the pleading practices and standards that existed the day before Twombly was decided. But what exactly were pleading practices prior to Twombly? Did attorneys rely on the liberal fair notice standard in framing a complaint? Or had a more fact-specific pleading practice and a heightened pleading standard already materialized?

Before answering these questions, two clarifications regarding terminology will be helpful. First, there is a distinction between "pleading practice" and "pleading standards." Pleading practice is how the plaintiff's attorney frames the complaint, including the extent to which the plaintiff's attorney includes information on the factual circumstances to support their claims. Pleading standards are the legal standards employed by the courts to determine if the complaint can survive a motion to dismiss for failure to state a claim. Most scholarly articles review decisions by courts when resolving motions to dismiss, and study pleading standards. ${ }^{18}$ Pleading practices, in

15. For a discussion of the burdens of pleading, see Alexander A. Reinert, Pleading as InformationForcing, 75 LAW \& CONTEMP. PROBS. 1 (on the burdens for claimants); Alexander A. Reinert, The Burdens of Pleading, 162 U. PA. L. REV. 1767 (2014) (on the burdens for judges).

16. Brian T. Fitzpatrick, Twombly and Iqbal Reconsidered, 87 Notre DAME L. Rev. 1621, 1631 (2012).

17. Jonah B. Gelbach, Selection in Motion: A Formal Model of Rule 12(B)(6) And the Twombly-IQbal Shift IN Pleading Practice 4 (footnote omitted), available at http://papers.ssrn.com/sol3/papers.cfm?abstract_id=2138428 (last visited June 18, 2013).

18. When we presented an early version of this paper at a 2013 conference, the resulting discussion became a "highly contentious slugfest" that ensued partially regarding the benefits of studying pleading practice in addition to pleading standards. ("The discussant argued that the FJC's focus on the realities of lawyers' practice was irrelevant to the Court's power-grab in Twombly, and that pleading standards mattered infinitely more than pleading practice." David Hoffman, CELS VIII: Data is Revealing, Part 1 (Oct. 29, 2013), http://www.concurringopinions.com/archives/2013/10/ cels-viii-data-is-revealing-part-1.html). Some especially enjoyed the discussion. ("As it was wrapping up, an economically-trained empiricist in the room commented how fun he had found it and how he hoped to see more papers on the topic of Twombly in the future." Hoffman, id. Much discussion focused on prior work by author Joe Cecil. That program of research does not directly concern pleading practice and will not be discussed herein but, rather, in an in-progress manuscript 
part, are responsive to pleading standards established by courts to assess the viability of complaints, but pleading practices may also be responsive to other factors as well. This Article is a study of pleading practices. It is important to note both the standard and practice actually used by attorneys. Even if the courts used a notice pleading standard, evidence that attorneys' pleading practice was more fact-based and akin to narrative pleading shows a disconnect worthy of research.

Second, this Article focuses on how the factual content of the complaint relates to Form 11 in the Appendix of Forms that accompanies the Federal Rules. We will further address the Forms in Part III, but for initial clarification purposes, Form 11 is the current, restyled version of Form 9. Form 9 was the original model complaint for automobile negligence, developed by the drafters in 1938, to illustrate the minimal requirements of a negligence complaint that would withstand a motion to dismiss. ${ }^{19}$ In Twombly, the Supreme Court endorsed the concise complaint in Form 9 as sufficient to overcome a motion to dismiss, ${ }^{20}$ while at the same time announcing a more demanding plausibility requirement, leading to much confusion over the continued vitality of Form $9 .{ }^{21}$ Form 11 grew out of the restyling of the Federal Rules and forms in December 2009, which was intended "to translate present text into clear language that does not change the meaning." 22 However, the restyled Form 11 removed two explicit statements from Form 9 that presented examples of facts surrounding the circumstances of the accident (i.e., while "crossing said highway;" "plaintiff was thrown down and had his leg broken"). Restyled Form 11 now offers an even leaner statement of the accident's factual circumstances (i.e., "On $<$ Date>, at <Place>, the defendant negligently drove a motor vehicle against the plaintiff."). While the restyled Form 11 is used as a reference point to assess complaints filed in 2006, in Part III the factual elements that appeared in Form 9 are noted, which was in effect at the time attorneys filed these complaints.

by that author. For a draft version, see Joe S. Cecil, Of Waves and Water: A Response to Comments on the FJC Study Motions to Dismiss for Failure to State a Claim After Iqbal (last updated Mar. 19, 2012), available at $\mathrm{http}: / / \mathrm{ssrn}$.com/abstract $=2026103$.

19. See Fed. R. Civ. P. APP. Forms A AND B.

20. Bell. Atl. Corp. v. Twombly, 550 U.S. 544, 590 n. 9 (2007).

21. For examples of efforts to reconcile the requirements of Twombly with the language of Form 9, see Adam N. Steinman, The Pleading Problem, 62 STAN. L. REV. 1293 (2010); Robert G. Bone, Twombly, Pleading Rules, and the Regulation of Court Access, 94 IowA L. REV. 873 (2009). Edward Cooper points out that the Supreme Court had little choice, since FED. R. CIV. P. 84 says that the forms in the Appendix to the rules "suffice under these rules . ..." Edward H. Cooper, King Arthur Confronts TWIQY Pleading, 90 OR. L. REV. 955, 966 n.30 (2012).

22. Edward H. Cooper, Restyling the Civil Rules: Clarity Without Change, 79 NotRe DAME L. Rev. 1761 (2004). 


\section{A. From Code pleading to Conley}

As stated by Miller, "History matters." 23 When the Federal Rules were adopted in 1938, the immediate goal was to lessen the burdensome nature of Code pleadings. The drafters wanted a more pragmatic method with more flexible rules and judicial discretion that would promote broad access to the courts for the common man. ${ }^{24}$ Judge Charles Clark sought to simplify pleading practices and ensure the pleadings gave fair notice of the general nature of the plaintiff's claims to the defendant. ${ }^{25}$ Whereas Code pleading required that the pleadings set forth the essential facts and specialized allegations in the complaint, Rule 8 requires only "a short and plain statement of the claim showing that the pleader is entitled to relief." ${ }^{26}$ With this liberal approach, more parties would be allowed to pass through the "doors to discovery," 27 the same "doors" that future scholars would state were being locked by the Twombly and Iqbal decisions. ${ }^{28}$

The liberal pleading standard faced early challenges. In 1955, the Advisory Committee rejected a proposal in response to Dioguardi $v$. Durning $^{29}$ that would have required the complainant to plead facts supporting the cause of action. ${ }^{30}$ The Advisory Committee stated that the original rule "adequately sets forth the characteristics of good pleading; does away with the confusion resulting from the use of "facts" and "cause of action"; and requires the pleader to disclose adequate information as the basis of his claim for relief as distinguished from a bare averment that he wants relief and is entitled to it." 31

23. Miller, supra note 5, at 3. For a further examination of the history of pleading from Thirteenth Century England to the time of the Federal Rules, see Hon. John P. Sullivan, Twombly and Iqbal: The Latest Retreat From Notice Pleading, 43 Suffolk U. L. Rev. 1, 8-13 (2009); and SCOTT DOdSON, NEW Pleading IN THE TwENTY-FiRST CENTURY (2013).

24. Dodson, supra note 23, at 17. See also 5 Charles Alan Wright \& Arthur R. Miller, FEDERAL PRACTICE AND PROCEDURE $§ 1218$ (3d ed. 2013) (for additional discussion of the history of pleading, including discussion of the Field Code).

25. DoDson, supra note 23, at 18.

26. FED. R. CIV. P. 8(a); see also Dioguardi v. Durning, 139 F.2d 774 (2d Cir. 1944); see generally Charles E. Clark, Simplified Pleading, 27 IowA L. Rev. 272 (1943) (defining and providing examples of Code pleading).

27. Jonah B. Gelbach, Locking the Doors to Discovery? Assessing the Effects of Twombly and Iqbal on Access to Discovery, 121 YALE L.J. 2270 (2012).

28. Id.; See also Andrew I. Gavil, Civil Rights and Civil Procedure: The Legacy of Conley v. Gibson, 52 How. L.J. 1, 14 (2008) (stating that, in Twombly, "the Court reached for the 'closed' instead of the 'open' sign it had held out for Conley.").

29. 139 F.2d at 774.

30. Advisory Comm. on Rules of Civil Procedure, Report of Proposed Amendments to the Rules of Civil Procedure for the United States District Courts 18-19 (Oct. 1955), available at http://www.uscourts.gov/uscourts/RulesAndPolicies/rules/Reports/CV10-1955.pdf.

31. Id. at 19 . 
In 1957, the Supreme Court endorsed this approach in Conley $v$. Gibson ${ }^{32}$ by stating that pleadings needed to meet the requirements of Rule 8 and "give the defendant fair notice of what the plaintiff"s claim is and the grounds upon which it rests" to survive a motion to dismiss. ${ }^{33}$ Conley became the benchmark case for fair notice, or notice pleading. The Court in Conley announced that "a complaint should not be dismissed for failure to state a claim unless it appears beyond doubt that the plaintiff can prove no set of facts in support of his claim . . ."34 Under Conley, judges rarely looked beyond the pleadings and, instead, accepted all factual (not conclusory) allegations as true, drawing inferences in favor of the pleader. The Conley standard allowed more cases to survive motions to dismiss and put the burden on discovery and summary judgment to dispose of unmeritorious claims. ${ }^{35}$ Code pleading was seemingly dead.

\section{B. Whither Notice Pleading?}

In the next 50 years, the Supreme Court generally upheld Conley and the notice pleading standard, with a few notable departures. ${ }^{36}$ Still, some lower courts "effectively ignored the standard while insisting on heightened or . . . fact pleading" in some cases. ${ }^{37}$ In 2003, Fairman found that targeted heightened pleading was "amazingly prevalent" 38 and that "every circuit applied some form of heightened pleading to conspiracy claims." ${ }^{39}$

32. Conley v. Gibson, 355 U.S. 41 (1957); see also Hickman v. Taylor, 329 U.S. 495 (1947) for an earlier discussion of the role of pleading. In Conley, the plaintiffs ("Negro members of the Brotherhood of Railway and Steamship Clerks") brought a class action lawsuit against their union, alleging that it did not protect them against a loss of employment when they were fired and replaced with white employees or similar-race employees with less seniority. Conley, 355 U.S. at 42.

33. Conley, 355 U.S. at $47-48$.

34. Id. at $45-46$.

35. See Swierkiewicz v. Sorema N.A., 534 U.S. 506, 512 (2002).

36. The uneven articulation of the notice pleading standard by the Supreme Court is discussed in DODSON, supra note 23, at 41-45 (identifying three Supreme Court cases as being in irreconcilable tension with the Conley notice pleading standard: Warth v. Seldin, 422 U.S. 490 (1975); Papasan v. Allain, 478 U.S. 265 (1986); and Dura Pharm., Inc. v. Broudo, 544 U.S. 336 (2005)). Miller, by contrast, characterizes the time between Conley and Twombly as "an impressive unbroken string of Supreme Court decisions repeating and reinforcing the norm of notice pleading." Miller, supra note 12, at 333 (noting a departure from the notice pleading standard by a number of federal courts).

37. Miller, supra note 5, at 18-19 (citing Christopher M. Fairman, The Myth of Notice Pleading, 45 ARIZ. L. REV. 987, 988 (2003)); see also Richard L. Marcus, The Revival of Fact Pleading Under the Federal Rules of Civil Procedure, 86 CoLum. L. Rev. 433, 435 (1986); Richard L. Marcus, The Puzzling Persistence of Pleading Practice, 76 Tex. L. ReV. 1749 (1998).

38. Fairman, supra note 37, at 1002-04. In particular, Fairman found that, in civil rights cases, some jurisdictions required specific evidence of unlawful intent when subjective intent was a prima facie element. Id.

39. Fairman, supra note 38, at 1033. 
Heightened pleading standards existed for many different case types, ranging from antitrust to $\mathrm{RICO}^{40}$ cases, ${ }^{41}$ and were "a long time in the making." ${ }^{42}$

Still, the Supreme Court endorsed notice pleading. In Leatherman $v$. Tarrant County Narcotics Intelligence \& Coordination Unit, the Court stated, "We think that it is impossible to square the "heightened pleading standard' [imposed by the U.S. Court of Appeals for the Fifth Circuit] . . . with the liberal system of "notice pleading' set up by the Federal Rules." 43 This was reaffirmed in Swierkiewicz v. Sorema N.A., when the Court found that a heightened pleading standard for employment discrimination cases violated Rule 8(a)(2). ${ }^{44}$ Only five months before Twombly, the Court, in Jones $v$. Bock, ${ }^{45}$ reaffirmed that "adopting different and more onerous pleading rules" is a task of the rules committees, not of the courts on a caseby-case basis. ${ }^{46}$

Though many districts pulled back on heightened pleading standards after Leatherman and Swierkiewicz, Fairman noted some districts continued the practice and heightened pleading, for one subjective intent element could "essentially eviscerate[ ] the entire claim." 47 In some instances, the lower courts appeared to directly oppose Supreme Court decisions striking down heightened pleading standards, even in civil rights cases resembling Leatherman and Swierkiewicz. In Oliver v. Scott, ${ }^{48}$ the Fifth Circuit Court of Appeals required plaintiffs to "allege specific conduct giving rise to a constitutional violation" 49 where government officials were sued in their individual capacities. Oliver, decided the same year as Swierkiewicz, directly contradicted the Leatherman decision. Four years later, the United States District Court for the District of Columbia, in Totten v. Norton, granted the government's motion to dismiss because the plaintiff "failed to allege facts sufficient to support one element of a prima facie case of retaliation," ${ }^{50}$ a higher standard than under Conley.

40. Racketeer Influenced and Corrupt Organizations Act (RICO), Pub. L. No. 91-452, 84 Stat. 922 (codified as 18 U.S.C. $\S \S 1961-1968$ (1970)).

41. Fairman, supra note 37; Fairman discusses the pleading practice in antitrust, Comprehensive Environmental Response, Compensation, and Liability Act (CERCLA), civil rights, conspiracy, copyright, defamation, negligence, and RICO cases.

42. Reinert, supra note 11, at 131. But see Reinert, 162 U. PA. L. REV. 1767, supra note 15, at 1771$72 \mathrm{n} .28$ (acknowledging that there were some "detours" from notice pleading by lower courts and citing Fairman's finding that notice pleading has rarely been the practice, but stating "this claim should not be overstated").

43. 507 U.S. $163,168(1993)$.

44. 534 U.S. 506, $512(2002)$.

45. 549 U.S. 199 (2007).

46. Id. at 224 .

47. Fairman, supra note 37 , at 1004 .

48. Oliver v. Scott, 276 F.3d 736 (5th Cir. 2002).

49. Id. at 741 .

50. Totten v. Norton, 421 F. Supp. 2d 115, 121 (D.D.C. 2006). 
Lower courts might have viewed the Supreme Court's dicta statement in Leatherman that there was "no occasion to consider whether [the Court's] qualified immunity jurisprudence would require a heightened pleading...." as punting the issue of heighted pleading, rather than seeking a return to notice pleading. Still, to some, cases defying notice pleading language "bordered on lawlessness." 52

This was not the first time the Supreme Court showed hesitancy (albeit, in dicta) to remove heightened pleading. In 1983, a footnote in the Court's opinion in Associated General Contractors v. California State Council of Carpenters maintained support for a heightened standard, stating that "a district court must retain the power to insist upon some specificity in pleading." ${ }^{53}$ A few courts also read the footnote in Associated General Contractors as a mandate for heightened pleading in antitrust cases. ${ }^{54}$ Similarly, in Justice Kennedy's concurrence in Siegert v. Gilley, he wrote that "the heightened pleading standard is a necessary and appropriate accommodation" 55 in qualified immunity analyses. Other courts might have interpreted Conley as a goal to achieve justice, rather than a literal rule that all pleadings suffice if they meet Conley standards. In fact, the United States Court of Appeals for the Seventh Circuit stated that the "exceedingly forgiving attitude towards pleading deficiencies ... in Conley . . . has never been taken literally." 56

Fairman concluded that notice pleading was "a myth," 57 showing that pleading standards in the years before Twombly were "a far cry from notice pleading" 58 and that the "rhetoric does not match the reality of federal pleading practice." ${ }^{59}$ However, Fairman also noted that notice pleading remained the dominant practice in complaints alleging negligence. This

51. Leatherman v. Tarrant Cnty. Narcotics Intelligence \& Coordination Unit, 507 U.S. 163, 166-67 (1993).

52. Burbank, supra note 3, at 6 (citing Perry v. Southeastern Boll Weevil Eradication Found., 154 F.App'x. 467, 472 (6th Cir. 2005); Danley v. Allen, 540 F.3d 1298, 1313-14 (11th Cir. 2008)).

53. Associated Gen. Contractors v. Carpenters, 459 U.S. 519, 528 n.17 (1983). The Court, however, did note that "we are perhaps stretching the rule of Conley ... too far." Id.

54. See Fairman, supra note 37, at 1017 n.198 (providing three examples of cases where the courts perceived the footnote as a mandate and imposed what Fairman refers to as hyperpleading).

55. Siegert v. Gilley, 500 U.S. 226, 235 (1991) (Kennedy, J., concurring)

56. Sutliff, Inc. v. Donovan Cos., 727 F.2d 648, 654 (7th Cir. 1984).

57. Fairman, supra note 37, at 988. The time before Twombly was considered a time of Conley notice pleading, but the research by Fairman shows that that was not the case across a wide number of case types. Though Fairman's assessment of the mythical nature of notice pleading might be a bit hyperbolic, when (if ever) notice pleading was the dominant pleading practice and standard warrants additional research.

58. Id. at 989. Fairman's article remains the most thorough review of pleading requirements across a wide range of case types.

59. Id. at 988. Fairman notes that despite the federal courts commonly referencing notice pleading and the Conley standard, heightened pleading standards became common. 
Article expands on Fairman's work and shows that, even in negligence cases, notice pleading practice was no longer the norm before Twombly or Iqbal. ${ }^{60}$

\section{Twombly, Iqbal, and After}

In Twombly, the plaintiffs, representing a class of local phone and highspeed Internet subscribers, sued a group of carriers for antitrust violations under the Sherman Act and alleged the carriers conspired to discourage competition. ${ }^{61}$ The United States District Court for the Southern District of New York granted the defendants' 12(b)(6) motions to dismiss, ${ }^{62}$ but the United States Court of Appeals for the Second Circuit reversed, holding that the plaintiffs stated a claim under the Conley standard. ${ }^{63}$ The Supreme Court reversed finding that the plaintiffs' twenty-eight-page, ninety-six-paragraph complaint was insufficient to survive a motion to dismiss. The Court stated, "[W]e do not require heightened fact pleading of specifics, but only enough facts to state a claim to relief that is plausible on its face." ${ }^{64}$ While the Court held that the allegations should be judged "in light of common economic experience," ${ }^{65}$ the opinion did not provide clear guidance on what made something plausible or whose experience should be considered. The Court announced that Conley had "earned its retirement." ${ }^{6}$ Justice Stevens noted, in his dissent, that the opinion was "the first by any Member of this Court to express any doubt as to the adequacy of the Conley formulation." 67 Yet, the Court also stated that it did "not apply any 'heightened' pleading standard...." 68 The Justices who joined the Twombly opinion stated that Twombly only "represented a relatively minor reorientation" and not a change that "could fundamentally alter the role of litigation in American society."69 Many commentators immediately disagreed, arguing that the Twombly decision sent "shockwaves" 70 through the lower courts.

60. Id. at 1051. Though even here Fairman found instances of courts requiring heightened pleading standards. Id.

61. Bell Atl. Corp. v. Twombly, 550 U.S. 544 (2007).

62. Twombly v. Bell Atl. Corp., 313 F. Supp. 2d 174 (S.D.N.Y. 2003).

63. Twombly v. Bell Atl. Corp., 425 F.3d 99 (2d Cir. 2005).

64. Twombly, 550 U.S. at 570 .

65. Id. at 565 .

66. Id. at 563 .

67. Id. at 578 (Stevens, J., dissenting).

68. Id. at 569 n.14 (majority opinion)

69. Stephen B. Burbank, Pleading And the Dilemmas of Modern American Procedure, 93 Judicature 109, 114 (2009). See also Adam McDonell Moline, Comment, Nineteenth Century Principles for Twenty First Century Pleading, 60 EMORY L.J. 159, 159 (2010); Martin H. Redish, Pleading, Discovery, and the Federal Rules: Exploring the Foundations of Modern Procedure, ENGAGE, Nov. 2011, at 145.

70. Colleen McMahon, The Law of Unintended Consequences: Shockwaves in the Lower Courts After Bell Atlantic Corp. v. Twombly, 41 SufFolK U. L. REv. 851 (2008). 
Two weeks after Twombly, the Court's per curiam opinion in Erickson v. Pardus unexpectedly reaffirmed support for the Conley standard, at least in pro se cases. ${ }^{71}$ In weighing a prisoner's civil rights complaint, the Court referenced Twombly, but only to cite the Conley fair notice standard. ${ }^{72}$ The Erickson opinion made no reference to the newly minted plausibility standard and did not clarify whether Twombly only applied to antitrust cases.

One month after Twombly, the Court ruled on the Private Securities Litigation Reform Act of 1995 (PSLRA), which created a heightened pleading standard for some securities claims and delayed discovery. ${ }^{73}$ The Court ruled that when pleading intent under the PSLRA, "an inference of scienter must be more than merely plausible or reasonable - it must be cogent and at least as compelling as any opposing inference of nonfraudulent intent." ${ }^{\prime 74}$ By interpreting this statutory standard as going beyond notice pleading and discussing levels of plausibility, the decision more closely resembled the plausibility standard in Twombly than the Conley standard. Still, the Court did not address how broadly lower courts should apply the Twombly plausibility standard in cases not covered by the PSLRA.

The answer came two years later in Ashcroft v. Iqbal. ${ }^{75}$ Javaid Iqbal, a Pakistani Muslim and pretrial detainee, alleged that United States government officials, including then Attorney General John Ashcroft, acted unconstitutionally by confining him and others in allegedly brutal conditions. ${ }^{76}$ The district court, citing Conley, denied most of the defendants' motions to dismiss. ${ }^{77}$ The United States Court of Appeals for the Second Circuit heard the case just after the Supreme Court's Twombly decision, and applied a plausibility standard, while also citing the Twombly footnote indicating that the Supreme Court did not intend to apply a heightened standard. ${ }^{78}$ The Second Circuit allowed most of the case to proceed, but the Court reversed in a 5-4 opinion. ${ }^{79}$

The Court in Iqbal did not refer to notice pleading or to the fair notice Conley language the Court had recently recited in Erickson. ${ }^{80}$ Instead, the

71. Erickson v. Pardus, 551 U.S. 89 (2007).

72. Id. at 93.

73. Private Securities Litigation Reform Act of 1995 (PSLRA), Pub. L. No. 104-67, 109 Stat. 737 (1995).

74. See Tellabs, Inc. v. Makor Issues \& Rights, Ltd., 551 U.S. 308 (2007).

75. 556 U.S. 662 (2009).

76. See Elmaghraby v. Ashcroft, No. 04 CV 01809 JG SMG, 2005 WL 2375202 (E.D.N.Y. Sept. 27, 2005).

77. Id.

78. Iqbal v. Hasty, 490 F.3d 143, 157 (2d Cir. 2007), rev'd 556 U.S. 662 (2009).

79. Iqbal, 556 U.S. 662.

80. Patricia W. Hatamyar, The Tao of Pleading: Do Twombly and Iqbal Matter Empirically?, 59 AM. U. L. REV. 553, 577 (2010) (also noting that the Court "omitted most of the ... (12)(b)(6) boilerplate language"). Hatamyar presents a thorough analysis of the 12(b)(6) language often cited by courts 
Court expanded the Twombly plausibility standard to all civil cases. ${ }^{81}$ The Court created a two-pronged approach to review motions to dismiss. ${ }^{82}$ First, the judge must remove all conclusory allegations from consideration and focus solely on factual allegations. ${ }^{83}$ Then, the judge must consider the remaining alleged facts through a subjective lens. The Court held that "determining whether a complaint states a plausible claim for relief will ... be a context-specific task that requires the reviewing court to draw on its judicial experience and common sense." 84 In doing so, the Court seemingly implied that, based on its judicial experience and common sense, the complaint failed to allege a plausible claim. Thus, the Court seemed to state that if the Second Circuit had properly applied its own judicial experience and common sense, it too would have found the complaint lacking. Providing only notice of the claims against a defendant was no longer enough to survive a motion to dismiss. ${ }^{85}$

As expected, a shift of this magnitude led to vigorous debate. ${ }^{86} \mathrm{~A}$ plausibility standard, combined with a judge's subjective analysis of the complaint, could lead to inconsistent rulings, since a clear factual allegation to one judge might be a conclusion to another. ${ }^{87}$ Some commentators wrote that the Twombly and Iqbal decisions "destabilized the entire system of civil

regarding factors such as how reasonable inferences are to be made to the benefit of the plaintiff. Id.

81. Iqbal, 556 U.S. at 678.

82. Id. at $679-80$.

83. Id.

84. Id. at 679 .

85. See Miller, supra note 5, at 19 (citing Tahir v. Import Acquisition Motors, LLC, No. 09 C 6471, 2010 WL 2836714 at $* 1$ (N.D. Ill. July 15, 2010)).

86. See Lisa Eichhorn, A Sense of Disentitlement: Frame-Shifting and Metaphor in Ashcroft v. Iqbal, 62 FLA. L. REV. 951, 959 (2010) (“[C]riticism of the Twombly decision was speedy and abundant.").

87. See Dan M. Kahan, David A. Hoffman \& Donald Braman, Whose Eyes Are You Going to Believe? Scott v. Harris and the Perils of Cognitive Illiberalism, 122 HARV. L. REV. 837 (2009); see also Lonny S. Hoffman, Burn up the Chaff with Unquenchable Fire: What Two Doctrinal Intersections Can Teach Us About Judicial Power over Pleadings, 88 B.U. L. Rev. 1217, 1257 (2008); Burbank, supra note 3, at 12; Miller, supra note 5. For further examples of how distinguishing factual allegations from conclusions can be difficult, see Papasan v. Allain, 478 U.S. 265 (1986). For a recent partial dissent questioning the implementation of Twombly and Iqbal, see Horras v. American Capital Strategies, Ltd., 729 F.3d 798 (8th Cir. 2013) ("This is an important development, but we must be careful not to embellish it.”); see also Robinson v. Beard, No. 08-3156, 2009 WL 2215088, at $* 2$ (E.D. Pa. July 22, 2009). See also Part V for additional discussions of the psychology of judicial decision making. 
litigation," 88 while others predicted that the effects were less likely to change pleading practice than some feared. ${ }^{89}$

According to Miller, the subjective prong invited an "inappropriate" level of "virtually unbridled discretion" $" 90$ that transformed the purpose of a Rule 12(b)(6) motion into a "potentially draconian method of foreclosing access." 91 This made it "harder for plaintiffs to find representation, even for potentially meritorious claims." 92 The new standard seemed to suggest a possible return to the "endless, technical bickering about distinctions between 'ultimate facts,' 'evidence,' and 'conclusions""93 that led to the adoption of the Federal Rules in 1938. Justice Ginsburg also expressed concern during the Second Circuit Judicial Conference in 2009 that she thought "the Court's majority messed up the Federal Rules." 94

A few years later, concerns still remain. In 2014, three Supreme Court cases addressed plausibility pleading. In May 2014, the Court cited Iqbal in its discussion of qualified immunity in Wood v. Moss,${ }^{95}$ but did not clarify how a judge "should evaluate allegations of a defendant's intent." 96 The following month, in response to allegations that the Internal Revenue Service had improper motives for issuing summonses, the Supreme Court in United States $v$. Clarke stated, "The taxpayer need only make a showing of facts that give rise to a plausible inference of improper motive." 97

88. Kevin M. Clermont \& Stephen C. Yeazell, Inventing Tests, Destabilizing Systems, 95 Iowa L. Rev. 821, 823 (2010); see also Miller, supra note 5, at nn.52, 53 for views of scholars in response to Twombly and Iqbal; see also Thomas P. Gressette, Jr., The Heightened Pleading Standard of Bell Atlantic Corp. v. Twombly and Ashcroft v. Iqbal: A New Phase in American Legal History Begins, 58 DRAKE L. REV. 401, 455 (2010) (stating that the decisions represented "the beginning of a new phase in the history of federal pleading requirements").

89. For earlier articles discussing how the predicted effects of Twombly are less likely to change pleading practice and doctrinal precedent as some fear, see Richard A. Epstein, Twombly After Two Years: The Procedural Revolution in Antitrust that Wasn't, GCP: ONLINE MAGAZINE FOR GLOBAL COMPetition Policy 1 (July 30, 2009); Robert G. Bone, Twombly, Pleading Rules, and the Regulation of Court Access, 94 IowA. L. REv. 873; see also Dobyns v. United States, 91 Fed. Cl. 412, 428 (2010) (finding that Twombly and Iqbal do not significantly alter how courts "should apply other long-standing pleading requirements").

90. See Miller, supra note 5, at 83.

91. Id. at 22 .

92. Id. at 67 .

93. Hatamyar, supra note 80 , at 557.

94. Ruth Bader Ginsburg, Remarks for Second Circuit Judicial Conference (June 12, 2009), available at www.supremecourtus.gov/publicinfo/speeches/viewspeech/sp_06-12-09.html.

95. 134 S. Ct. 2056 (2014).

96. Adam Steinman, SCOTUS Decision in Wood v. Moss: Guidance on Pleading Standards?, CIV. ProCedure \& Fed. CourTs Blog (May 27, 2014), http://lawprofessors.typepad.com/civpro/ 2014/05/scotus-decision-in-wood-v-moss-guidance-on-pleading-standards.html (finding that "At first glance, Wood does not seem to provide a conclusive resolution" and then stating that "the presence of an objectively reasonable security rationale doomed the plaintiffs' claims even if viewpoint discrimination also played a role.").

97. United States v. Clarke, 134 S. Ct. 2361 (2014); see also Patricia W. Moore, SCOTUS: IRS Summons Challenger Must Show Facts Giving Rise to Plausible Inference of Improper IRS Motive, Civ. Procedure \& Fed. Courts Blog (June 20, 2014), http://lawprofessors.typepad.com/ 
Then, in November 2014, the Supreme Court, in Johnson v. City of Shelby, reminded that a plaintiff "must plead facts sufficient to show that her claim has substantive plausibility"98 but also stressed that the petitioners, on remand, should be allowed to amend their complaint. This emphasis, and the Court's desire to "ward off further insistence on a punctiliously stated 'theory of the pleadings," 99 led early commentators to note "an appearance of possible sheepishness about Twombly"100 and a "more sensible approach to pleading generally." 101

Over the next few years, one hopes the Court will clarify the plausibility pleading standard and better explain how a judge should invoke judicial experience and common sense when making those determinations. ${ }^{102}$

This Article does not seek to defend the Twombly and Iqbal decisions. Although we find that narrative pleading practice emerged before Twombly and Iqbal (at least in two federal case types), the decisions raise some concerns. First, the decisions provide a complicated standard for resolving motions to dismiss that invites cognitive biases and disagreement over proper interpretation of the parties' obligations and the extent to which judges should anticipate the success of discovery at an early stage of litigation. ${ }^{103}$ Second, the decisions circumvented the long-established procedure established by the judicial branch to allow public comments and broad participation in the development of federal rules. ${ }^{104}$ Third, emerging

civpro/2014/06/scotus-irs-summons-challenger-must-show-facts-giving-rise-to-plausible-

inference-of-improper-irs-motive.html.

98. Johnson v. City of Shelby, No. 13-1318 at 2-3 (U.S. Nov. 10, 2014) (per curiam).

99. Id. at 3 .

100. Barry Barnett, Twombly's Remorse?, Blawgletter (Nov. 10, 2014), http://blawgletter.typepad.com/bbarnett/2014/11/twomblys-remorse.html.

101. Adam Steinman, Some Thoughts on Johnson v. City of Shelby: Does It Help Make Sense of Twombly \& Iqbal?, Civ. Procedure \& FED. COURTS Blog (Nov. 17, 2014), http://lawprofessors.typepad.com/civpro/2014/11/some-thoughts-on-johnson-v-city-of-shelbydoes-it-help-make-sense-of-twombly-iqbal.html.

102. While this Article refers only to federal court practice, it is of note that state courts have also adopted the plausibility pleading standard. In July 2014, the Wisconsin Supreme Court adopted the standard in Data Key Partners v. Permira Advisers LLC, 2014 WI 86, 849 N.W.2d 693. See Patricia W. Moore, Wisconsin Adopts Twombly's Plausibility Standard, Civ. Procedure \& Fed. CourTS BLOG (July 25, 2014), http://lawprofessors.typepad.com/civpro/2014/07/wisconsin-adoptstwomblys-plausibility-standard.html. However, the Minnesota Supreme Court rejected the standard shortly thereafter in Walsh v. U.S. Bank, N.A., 851 N.W.2d 598 (Minn. 2014). See Patricia W. Moore, Minnesota Supreme Court Rejects Twiqbal (Aug. 7, 2014), http://lawprofessors.typepad.com/civpro/2014/08/minnesota-supreme-court-rejects-twiqbal-.html.

103. For further discussion of decision making concerns and cognitive bias, see Part V. C. infra.

104. The Federal Rules are amended under a delegation of authority under the Rules Enabling Act, 28 U.S.C. $\$ 2072$ (2006). See Steven B. Burbank, Summary Judgment, Pleading, and the Future of Transsubstantive Procedure, 43 AKRON L. Rev. 1189 (2010), and Brooke D. Coleman, Deserving of Attention: The Proposed Abrogation of Civil Rule 84 \& the Official Forms, PATENTLYO BLOG (Feb. 24, 2014), http://patentlyo.com/patent/2014/02/deserving-attention-abrogation.html. For a discussion of rulemaking by the committee process, see Stephen B. Burbank, Pleading and the Dilemmas of "General Rules," 2009 WIS. L. REv. 535, 537 (2009); Robert G. Bone, Plausibility 
empirical research on disadvantaged groups finds that Twombly and Iqbal negatively affected disadvantaged plaintiffs in certain types of cases. ${ }^{105}$ Continued investigation into this important line of research is necessary. Fourth, the Twombly and Iqbal decisions do not recognize the ability and skill with which district court judges manage difficult issues concerning motion practice and the cost of discovery. ${ }^{106}$ Finally, the decisions sparked an increase in motions to dismiss by defendants and motions to amend, thereby increasing the costs to the parties and requiring judges to spend more time resolving additional motions. ${ }^{107}$

In response to Twombly and Iqbal, some attempted to override the decisions and restore the notice pleading standard. ${ }^{108}$ The Notice Pleading Restoration Act of 2009 sought to "provide that Federal courts shall not dismiss complaints under rule 12(b)(6) . . . except under the standards set forth" in Conley. ${ }^{109}$ The bill did not leave the Senate Judiciary Committee. ${ }^{110}$ The United States House of Representatives proposed its own bill, the Open Access to Courts Act of 2009, to restore notice pleading under Conley. ${ }^{111}$

Pleading Revisited and Revised: A Comment on Ashcroft v. Iqbal, 85 NOTRE DAME L. Rev., 849, 883-85 (2010); Catherine T. Struve, The Paradox of Delegation: Interpreting the Federal Rules of Civil Procedure, 150 U. PA. L. REv. 1099, 1133-36 (2002); Jack B. Weinstein, Reform of Federal Court Rulemaking Procedures, 76 ColuM. L. Rev. 905, 908 (1976).

105. For example, see Joseph A. Seiner, The Trouble with Twombly: A Proposed Pleading Standard for Employment Discrimination Cases, 2009 U. ILl. L. Rev. 1011; Victor D. Quintanilla, Beyond Common Sense: A Social Psychological Study on Iqbal's Effect on Claims of Race Discrimination, 17 Mich. J. RACE \& L. 1 (2011); Raymond H. Brescia, The Iqbal Effect: The Impact of New Pleading Standards in Employment and Housing Discrimination Litigation, 100 Ky. L.J. 235 (2012). For a further examination of Brescia's work, see Part III infra.

106. Bell Atl. Corp. v. Twombly, 550 U.S. 544, 559 (2007) ("It is no answer to say that a claim just shy of a plausible entitlement to relief can, if groundless, be weeded out early in the discovery process through 'careful case management', . . . given the common lament that the success of judicial supervision in checking discovery abuse has been on the modest side.") (internal citations omitted).

107. However, research by one of us finds that they have little if any effect in the outcome of litigation. See Joe S. Cecil et al., Fed. Judicial Ctr., Motions to Dismiss for Failure to State a Claim After Iqbal: RePort to the Judicial CONFERENCE AdVisory COMMITTEe ON CiviL RULES, (Mar. 2011), available at http://www.fjc.gov/public/pdf.nsf/lookup/motioniqbal.pdf/ \$file/motioniqbal.pdf; Joe S. Cecil et al., Fed. Judicial Ctr., Update on Resolution of Rule

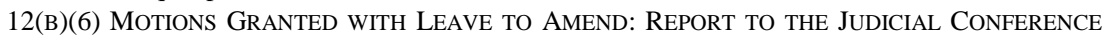
Advisory COMmitteE ON Civil RULEs, at vii (Nov. 2011), available at http://www.fjc.gov/public/pdf.nsf/lookup/motioniqbal2.pdf/\$file/ motioniqbal2.pdf.

108. See Clermont \& Yeazell, supra note 88, at 856-59.

109. Notice Pleading Restoration Act of 2009, S. 1504, 111th Cong. (2009) available at http://www.govtrack.us/congress/bills/111/s1504/text.

110. Id.

111. Open Access to Courts Act of 2009, H.R. 4115, 111th Cong. (2009), available at http://www.govtrack.us/congress/bills/111/hr4115. This Act would prohibit a federal court "from dismissing a complaint: (1) unless it appears beyond doubt that the plaintiff can prove no set of facts in support of the claim which would entitle the plaintiff to relief; or (2) on the basis of a determination by the judge that the factual contents of the complaint do not show the plaintiff's claim to be plausible or are insufficient to warrant a reasonable interference that the defendant is liable for the misconduct alleged." Id. 
Again, despite hearings on the matter, the bill quickly died. ${ }^{112}$ These attempts generally ignored that many lower courts already started to chip away at the Conley standard before Twombly, and rarely acknowledged whether the current pleading practice could still be defined as notice pleading.

Even if the acts are reintroduced into Congress, they are unlikely to garner much interest, as "the reinstatement of Conley will not . . . appease political concern" 113 and "is quite unlikely and probably undesirable." 114 Still, a concern with these congressional acts and their progeny is the notion that restoring the world to the day before Twombly restores pleading to a uniform notice pleading standard and practice. Forcing courts to return to the Conley standard requires courts to ignore a wide swath of decisions where some courts acknowledged heightened pleading standards for some cases, ${ }^{115}$ and ignores that attorneys' pleading practices were already more akin to narrative pleading than notice pleading before Twombly.

\section{BRIEF REVIEW OF RELATED STUDIES}

The past few years have brought about many reviews and empirical studies assessing whether judicial decisions on motions to dismiss changed after Twombly and Iqbal. All appear to assume that litigants and courts, prior to Twombly, were following the notice pleading standard. As Judge Ellis aptly stated, "the debate over the merits and demerits of Iqbal and Twombly has been characterized by almost as much heat as light." 116

Traditional legal scholarship examining pleading standards relies on published court decisions to draw inferences about changes in pleading standards over time. Recently, more rigorous empirical studies of district court decisions have used systematic coding and statistical analyses to understand the effect of changes in pleading standards across more representative sets of cases. Both of these approaches assume that attorney pleading practices match the standards articulated by the courts in opinions

112. For more information on the Acts and the written statements for the record and testimony regarding them, see Has the Supreme Court Limited Americans' Access to Courts?, Hearing Before the S. Comm. On the Judiciary, 111th Cong. (2009), available at http://www.gpo.gov/fdsys/pkg/CHRG111shrg56719/pdf/CHRG-111shrg56719.pdf; Burbank, supra note 3.

113. Calvar, supra note 5, at 220.

114. Miller, supra note 5, at 99. This Article does not take a position regarding future legislation or amendments to the Federal Rules. For a review of possible amendments to the Federal Rules of Civil Procedure that would take into account the standards of Twombly and Iqbal, see generally Edward H. Cooper, King Arthur Confronts TWIQY Pleading, 90 OR. L. REV. 955 (2012).

115. See Fairman, supra note 37; Richard L. Marcus, The Revival of Fact Pleading Under the Federal Rules of Civil Procedure, 86 Colum. L. Rev. 433 (1986); Brian T. Fitzpatrick, Twombly and Iqbal Reconsidered, 87 NOTRE DAME L. REV. 1621, 1622 (2012) (stating that "as a practical matter, lower federal courts long ago elevated pleading standards in the face of the exponential increases in discovery costs faced by corporate defendants").

116. And we certainly accept a share of the responsibility. See Ellis \& Shah, supra note 13, at 64. 
resolving motions to dismiss. This Article employs a third approach by directly examining individual complaints to determine the manner in which attorneys presented and supported the causes of action, and how these pleading practices relate to the pleading standards articulated by the courts. This is not a study of how the standards have or have not changed the resolution of dispositive motions and does not seek to support or critique prior studies. Still, we will briefly review past studies when they provide context for this pleading practice research and provide a pattern of findings that may be explained, at least in part, by the results of this study. ${ }^{117}$

In a review of twelve studies regarding the effects of Twombly and Iqbal, Engstrom concluded that the studies demonstrated that Twombly and Iqbal provided "at most a single-digit impact on the observed rate at which judges have granted 12(b)(6) motions (i.e., the judicial behavior effect), and this is true of orders with and without plaintiff-excluding effect." 118 Of course, very little change would be expected if narrative pleading practice had already become prevalent before the Twombly or Iqbal decisions.

117. Initial empirical analyses of the judicial response to the Supreme Court decisions focused solely on the pre-Iqbal period and examined potential differences between motion to dismiss grant rates in the Conley era and the period between Twombly and Iqbal. Kendall W. Hannon, Note, Much Ado About Twombly? A Study on the Impact of Bell Atlantic Corp. v. Twombly on 12(b)(6) Motions, 83 Notre Dame L. Rev. 1811 (2008); Seiner, supra note 105; Joseph A. Seiner, Pleading Disability, 51 B.C. L. Rev. 95 (2010); William H.J. Hubbard, The Problem of Measuring Legal Change with Application to Bell Atlantic v. Twombly (Univ. of Chi. Law \& Econ., Olin Working Paper No. 575, 2011), available at http://ssrn.com/abstract=1883831. For example, in one of the first empirical studies, Hannon examined cases brought before and soon after the Twombly decision, and found that "the new linguistic veneer that the Court has placed on Rule 8(a) and 12(b)(6) appears to have had almost no substantive impact" with the exception of civil rights cases. Hannon, supra, at 1815 (finding that motions to dismiss in civil rights cases were more likely to be granted following Twombly). Hannon did not distinguish between motions to dismiss granted with leave to amend the complaint and motions to dismiss granted without leave to amend. Hubbard examined the outcome of motions in cases filed before the Twombly decision and resolved after that decision (thereby controlling for changes by plaintiffs in the selection of cases filed) and found no effect of Twombly on the outcome of those cases. Hubbard, supra. However, research on the outcome of motions to dismiss resolved in the interim period between the Supreme Court decisions on Twombly and Iqbal might provide only limited guidance. As Hannon readily states of that time period: "faced with interpreting Twombly, many judges have found uncertainty and confusion." Hannon, supra, at 1814 (footnote omitted). In this ambiguous period, the appellate courts had not yet interpreted the Twombly decision. That is not to say that Iqbal brought clarity, but that assessments of motion to dismiss rates in this period should be interpreted cautiously.

118. David Freeman Engstrom, The Twiqbal Puzzle and Empirical Study of Civil Procedure, 65 STAN. L. REv. 6, 29-30 app.A (2013). The "plaintiff-excluding effect" is based on Jonah Gelbach's model that attempts to take into account decisions by plaintiffs to not file cases that would have been filed before Iqbal, or to settle cases for a lesser value after Iqbal. Engstrom's meta-analysis demonstrates that the more rigorous studies estimate either no effect or a very modest effect while studies lacking in rigor tend to have greater estimates of effect. Id. Engstrom is critical of some studies because, as a group, they tend not to focus on the party, fail to take into account the dynamic nature of litigation that may result in changes in litigation practice, and fail to assess the costs and benefits of judges' implementation of these standards on the overall fairness of the litigation process. Id at 1830. See also Gelbach, supra note 27. 
Two recent studies include findings that relate to the vitality of notice pleading before Twombly. Both of these studies attempted to distinguish between motions to dismiss that were granted due to insufficient facts, and those that were granted due to legal insufficiencies. While both studies claim to find an increase in motions granted due to insufficient facts after Iqbal, the real surprise is how common dismissals for factual insufficiency were before Twombly.

In 2012, Raymond Brescia conducted a focused study of employment and housing discrimination cases, which have often been the object of motions to dismiss. ${ }^{119}$ Unlike previous studies, Brescia restricted his examination to only those orders that assessed the factual specificity of the pleadings. The orders were filed during a continuous period starting before Twombly in 2004 and ending after Iqbal in 2010. ${ }^{120}$ Of interest, Brescia found that even before Twombly, $61 \%$ of the motions were granted at least in part due to an insufficient presentation of facts in the complaint. ${ }^{121}$ Brescia also found that courts did not follow the two-part test in Iqbal. ${ }^{122}$ Brescia noted that Twombly and Iqbal were often mentioned only in boilerplate language, and then disregarded. ${ }^{123}$ Judges, in more than half of the cases where motions to dismiss were granted in full, ruled without applying any plausibility standard. ${ }^{124}$ Of the ninety-five analyzed cases, district courts only applied the plausibility test in four cases ${ }^{125}$ and made a tangential reference to the judges' own experience and common sense, as recommended by the Supreme Court, in only one case. ${ }^{126}$ While Twombly and Iqbal "seem to represent a departure from a notice-pleading regime," ${ }^{127}$ Brescia found that the proposed plausibility standard had less of an impact than expected. ${ }^{128}$ Many courts "simply applied a relatively straightforward and traditional Rule 8 (a) analysis" more akin to notice pleading. ${ }^{129}$

119. See generally Brescia, supra note 105. However, this study faces its limitations. For example, employment and housing discrimination cases could also be affected by the economic downturn, just as financial instruments cases likely were. The subject matter of these cases in the post-Iqbal era could be more closely tied to firings and foreclosures due to the recession, and, if the subject matter of the complaint changes, it could add additional confounds when trying to examine how motion practice changed over time.

120. Id. at 261.

121. Id. Brescia also found that the rate of dismissals based on factual insufficiency increased to $72 \%$ following Iqbal.

122. Id.

123. $I d$. at 278 .

124. Id. at 278-80. Some have mentioned the frequency with which these cases have been cited as an indication of the extent to which they have changed pleading practice. But such citation counts are likely a poor indicator of the extent of the influence of these opinions.

125. Id. at 279 .

126. Id. at 284 .

127. Id. at 287 .

128. Id. at $278-79$.

129. Id. at 279 . 
In 2013, Scott Dodson examined approximately 2400 opinions resolving motions to dismiss, including about 1200 opinions decided the year before Twombly. ${ }^{130}$ Dodson found that, even before Twombly, $25.3 \%$ of the dismissed claims were dismissed on the basis of insufficient facts. ${ }^{131}$ Dodson concluded, "Clearly Rick Marcus and Chris Fairman were right: Even before Twombly, lower courts were holding a significant number of claims to a pleading standard not recognized (and arguably disavowed by the Supreme Court)." 132

This confirmed earlier findings that, despite Rule 8's statement that complaints should be both "short and plain," 133 some complaints exceeded 4000 pages and included "voluminous details." 134 With notice pleading, there should be no need for such a verbose complaint, as fair notice alone should allow the case to continue and survive a motion to dismiss. Additionally, orders resolving motions on the basis of insufficient facts should not occur at this rate. Combined with the empirical analysis that, especially in employment and housing discrimination cases, departure from the strict form of notice pleading as intended by the drafters was common prior to Twombly, there is ample evidence to question if notice pleading was the uniform standard in the time just prior to Twombly.

While little research has examined pleading practice, in 2012, Emery Lee surveyed about 1500 plaintiff and defendant attorneys regarding the early stages of litigation and asked attorneys whether their pleading practices changed since Twombly and Iqbal and, if so, how the pleading practices had changed. ${ }^{135}$ Only half of the attorneys reported their pleading practices changed, with almost all, 92\%, reporting they included more facts in complaints. ${ }^{136}$ We do not doubt that attorneys now include more facts when faced with the plausibility standard. ${ }^{137}$ Instead, the present research establishes that attorney practice had already exceeded the requirements of the notice pleading standard before Twombly was decided and, thus,

130. DODSON, supra note 23, at 98 tbl3.3.

131. Id. Dodson also found that the rate of dismissals based on factual insufficiency increased to $47.9 \%$ following Iqbal. Dismissals based on insufficient legal allegations dropped following Iqbal, from $50.2 \%$ to $43.2 \%$. Id. at 98 tbl.3.4.

132. Id.

133. FED. R. CIV. P. 8(a); Id. 8(e).

134. Fairman, supra note 37, at 1009-11 (citing Gordon v. Green, 602 F.2d 743 (5th Cir. 1979)).

135. Emery G. Lee III, Fed. Judicial Ctr., Early Stages of Litigation Attorney Survey, RePort to the Judicial Conference Advisory CommitTeE on Civil Rules 8 (Mar. 2012). This study was in response to the Civil Rules Advisory Committee's "continued interest in the impact of Twombly and Iqbal."

136. Id. at 8,16 . In addition, $28 \%$ of attorneys reported more factual investigation prior to filing a complaint. Id. However, it is of note that these findings are due to self-reporting by the attorneys, not an investigation of the complaints themselves. We do not dispute that Twombly and Iqbal likely increased the use of facts in complaints, and preliminary research has found that narrative pleading practice has become more detailed after Iqbal. See Section V infra.

137. In fact, we have done preliminary research that confirms this belief. See infra note 253. 
Twombly and Iqbal were not the cause of this shift from notice pleading to narrative pleading practice.

\section{FEDERAL FORMS AND STUDY METHODOLOGY}

Judge Clark, a principal drafter of the Federal Rules, wrote in 1925 that pleading is a flexible standard and that "no system of pleading yet devised may be considered final, and ... unless pleading rules are subject to constant examination and revaluation, they petrify, and become hindrances, not aids, to the administration of justice." 138 As shown in Part II, some courts had already replaced the notice pleading standard with more detailed pleading standards in some cases, though not for negligence cases. ${ }^{139}$

We examined complaints in federal automobile accident negligence cases (common, both in their number and their geographic diversity) filed before the Twombly decision and found that even here, a more fact-intensive pleading practice dominated. The facts required to plead a federal automobile accident case are fairly simple and are represented by the illustrative Form 11, Complaint for Negligence (formerly Form 9) in the Appendix of Forms accompanying the Federal Rules, thereby offering a distinctive opportunity to compare current pleading practice to the notice pleading practice intended by the drafters. ${ }^{140}$

\section{A. Forms: Past, Present, and Future}

When formulating the Federal Rules, the Advisory Committee attached forms "showing how very little was required of plaintiffs" 141 and these forms have remained a vestige of the drafters' original intentions. Federal Rule of Civil Procedure 84 states the Forms are "sufficient under the rules" for the purpose of promoting simplicity. ${ }^{142}$ Responding to early concerns that the form "would be insufficient in any court of law," it was stated that "very few courts would hold such a general statement wholly invalid; that is, would

138. Clark, supra note 27 , at 545 .

139. See Fairman, supra note 37; Marcus, supra note 37.

140. See FED. R. CIv. P. Form 11, available at http://www.uscourts.gov/RulesAndPolicies/ FederalRulemaking/RulesAndForms/IllustrativeCivilRulesForms.aspx. At the time of the adoption of the Federal Rules, this was designated as Form 9. See also Fairman, supra note 37, at 1000 (describing simplified notice pleading as referring "to short and plain statements of a claim that embody the simplicity of both Rule 8 and the Federal Forms"). As stated supra in Part II, in December 2009, the Federal Rules and related forms were restyled and Form 9 became Form 11. Note that the restyled Form 11 is even more austere than the original Form 9, using place markers for the date and place of the accident, and not mentioning the nature of the injury.

141. Burbank, supra note 3, at 5; see also Coleman, supra note 104.

142. FED. R. CIV. P. 84. 
hold that it did not state a cause of action."143 Judge Clark stated "that this affords adequate basis for res judicata is clear" 144 and that the Forms were "the most important part of the rules." 145 Notice pleading, the Federal Rules, and the Forms eventually combined to generally form one consistent pleading practice. ${ }^{146}$ Form 11 illustrates the intended principles of the Federal Rules.

After a statement of jurisdiction, Form 11 (the restyled version of the Form 9 negligence complaint form discussed in Twombly) ${ }^{147}$ requires plaintiffs to complete the following:

2. On $\langle$ Date $>$, at $\langle$ Place $>$, the defendant negligently drove a motor vehicle against the plaintiff.

3. As a result, the plaintiff was physically injured, lost wages or income, suffered physical and mental pain, and incurred medical expenses of $\$<\ldots$

Therefore, the plaintiff demands judgment against the defendant for $\$<\ldots$ _ , plus costs. ${ }^{148}$

In Twombly, the Supreme Court showed some support for Form 9. ${ }^{149}$ However, lower courts were uncertain about the continued vitality of the Forms. In Doe ex rel. Gonzales v. Butte Valley Unified School District, the district court granted the defendant's motion to dismiss with leave to amend and noted that the Forms "have been cast into doubt by Iqbal." 150

In response to "uncertainties about the impact of the Supreme Court's still recent decisions on pleading standards," 151 a subcommittee of the

143. Burbank, supra note 3, at 10 (citing AM. BAR Ass'N., Federal Rules of Civil Procedure: PRoCEEdings of THe Institute at Cleveland, OHIO 222, 223 (1938)).

144. Dodson, supra note 23, at 21 (citing Charles E. Clark, Simplified Pleading, 2 F.R.D. 456, 460-61 (1943). See also, Fairman, supra note 37, at 1048 ("When Charles Clark envisioned the prototype of notice pleading, he selected a negligence claim —an automobile accident. Federal Form 9 embodies the simplicity of notice pleading such a claim. The four-sentence 'Complaint for Negligence' includes only the date and location, the allegation that 'defendant negligently drove a motor vehicle against plaintiff,' and a general description of damages. Even a complaint this brief satisfies the Rule 8 standard.") (footnote omitted).

145. Dodson, supra note 23, at 20 (citing Charles E. Clark, Pleading Under the Federal Rules, 12 Wyo. L. REV. 177, 191 (1958)).

146. The Federal Rules, however, did address a few exceptions to the rule. Notably, Federal Rule 9(b) addresses additional facts needed when alleging fraud. FED. R. CIV. P. 9(b).

147. See FED. R. CIV. P. Form 11.

148. Id.

149. Bell Atl. Corp. v. Twombly, 550 U.S. 544, 576 n.10 (2007) (providing the template for a negligent complaint as "On June 1, 1936, in a public highway called Boylston Street in Boston, Massachusetts, defendant negligently drove a motor vehicle against plaintiff who was then crossing said highway.").

150. No. CIV. 09-245 WBS CMK, 2009 WL 2424608, at *8 (E.D. Cal. Aug. 6, 2009); see also Iodice v. United States, 289 F.3d 270 (4th Cir. 2002).

151. Memorandum from Hon. David G. Campbell, Chair, Advisory Comm. on Fed. Rules of Civil Procedure, to Hon. Jeffrey S. Sutton, Chair, Standing Comm. on Rules of Practice and Procedure 
Advisory Committee on Civil Rules to the Judicial Conference Committee on Rules of Practice and Procedure examined the role of the Forms and, in its May 2013 report, stated that "the best approach is to abrogate Rule 84 and the Rule 84 forms." 152 The subcommittee found that the Forms "have come to seem inadequate." 153 The proposal to abrogate Rule 84 came alongside a package of proposed amendments in response to concerns of excessive cost and inefficiencies in federal civil litigation, expressed at a national conference at Duke Law School (the Duke Conference). ${ }^{154}$

The proposed amendments were submitted for public comment in August $2013^{155}$ and generated more than 2300 public comments, which were generally directed to the proposed amendments growing out of the Duke Conference. ${ }^{156}$ At least thirty comments directly addressed the proposed amendment to abrogate Rule 84 and the related forms, with almost twenty comments from members of the legal academy expressing their opposition. The Advisory Committee attributed this opposition "to continuing unease

60 (May 8, 2013), available at http://www.uscourts.gov/uscourts/RulesAndPolicies/rules/ Reports/CV05-2013.pdf.

152. Id. at $6111.2352-53$.

153. Id. at 1. 2368. These recommendations were approved by the Judicial Conference Committee on Rules of Practice and Procedure at its May 2014 meeting and forwarded to the Judicial Conference for consideration. Concerns about the Forms do not focus solely on the negligence form. The suitability of Form 18 for patent infringement complaints is of concern. Some courts have expressed concern that Form 18 does not suffice and that using the form for patent infringement complaints is inadequate to survive a motion to dismiss. See Macronix Int'l Co. v. Spansion, Inc., 4 F. Supp. 3d 797 (E.D. Va. 2014). This comes after a series of decisions that a complaint that conforms to Form 18 is adequate to defeat a motion to dismiss for failure to state a claim despite the heightened standards for pleading announced by the Supreme Court in Twombly and Iqbal. See K-Tech Telecomms., Inc. v. Time Warner Cable, Inc., 714 F.3d 1277 (Fed. Cir. 2013); McZeal v. Sprint Nextel Corp., 501 F.3d 1354, 1356-57 (Fed. Cir. 2007); Microsoft Corp. v. Phoenix Solutions, Inc., 741 F. Supp. 2d 1156 (C.D. Cal. 2010) (“'[A] declaratory judgment claim of no direct infringement need only plead facts to put the patentee on notice and need not be subject to the heightened pleading standards of Twombly and Iqbal.").

154. See 2010 Civil Litigation Conference, U.S. COURTS, http://www.uscourts.gov/RulesAndPolicies/rules/archives/projects-rules-committees/2010-civillitigation-conference.aspx (last visited Nov. 4, 2014). This controversial package of amendments sought to improve the dispositions of civil actions "by advancing cooperation among the parties, proportionality in the use of available procedures, and early and active judicial case management." Memorandum from Hon. David G. Campbell, Chair, Advisory Comm. on Fed. Rules of Civil Procedure, to Hon Jeffrey S. Sutton, Chair, Standing Comm. on Rules of Practice and Procedure (June 14, 2014). After considering the comments, the Advisory Committee recommended the withdrawal of proposed amendments that would have lowered the presumptive numbers of depositions and interrogatories, limited the presumptive number of requests to admit, and reduced the presumptive length of depositions. Id.

155. Memorandum from Hon. Jeffrey S. Sutton, Chair, Comm. on Rules of Practice and Procedure to The Bench, Bar, and Public (Aug. 15, 2013), available at http://www.uscourts.gov/uscourts/ rules/preliminary-draft-proposed-amendments.pdf.

156. The number of comments understates the extent of the legal academy's opposition to the abrogation of Rule 84 . 
over the direction of contemporary federal pleading standards." ${ }^{157}$ Two submitted comments opposed to the amendments were subscribed to by numerous legal academics. A comment from Professor Siegel, which was endorsed by 110 other law professors, objected to abrogation of the Forms, contending that the Forms are needed not to guide litigants but, instead, to constrain the actions of judges who are otherwise acting in violation of the law. ${ }^{158}$ A second comment from Professors Hershkoff, Steinman, Hoffman, Schneider, Reinert, and Shapiro endorsed by 171 other law professors, objected to the abrogation of the Forms as an indirect refutation of notice pleading and adoption of the plausibility pleading standard of Twombly and Iqbal. ${ }^{159}$ The comment also objected to the lack of empirical evidence to

157. Memorandum from Hon. David G. Campbell, Chair, Advisory Comm. on Civil Rules, to Hon. Jeffrey S. Sutton, Chair, Comm. on Rules of Practice and Procedure 412 (May 2, 2014), available at http://www.uscourts.gov/uscourts/RulesAndPolicies/rules/Agenda\%20Books/Standing/ ST2014-05.pdf. See, e.g., Comment from Arthur Miller 22 (Jan. 6, 2014), available at http://www.lfcj.com/uploads/3/8/0/5/38050985/frcp_arthur_miller_1.9.14.pdf (Abrogation of the Forms "will be construed as the rulemakers' acceptance — or implicit codification—of plausibility pleading under Twombly and Iqbal when in reality there has not been any fundamental reexamination of the possible deleterious effects of those cases' return to fact pleading, or any comprehensive or penetrating empiric research on the subject, or an exploration of other possible Rule amendments to meet the concerns defense interests have voiced over the years but which have not been established. There really is no reason to take this action at this time; it is premature."). One legal scholar also suggested that eliminating the Forms by abrogation of Rule 84 was a violation of the Rules Enabling Act. See Comment from Brooke Coleman 1 (Feb. 7, 2014), available at http://www.lfcj.com/uploads/3/8/0/5/38050985/frcp_seattle_university_school_of_law._brooke_c oleman_2.7.14.pdf ("I believe that the proposed abrogation of Rule 84 and the Official Forms is a violation of the Rules Enabling Act process. In short, the rules and the forms are one and the same. In order to understand the rule, one must look to the forms. This means that in order to change a form, the rule and the form to which it corresponds must be changed together. This is because a change to the form necessarily changes the rule to which it corresponds, meaning that both the form and rule must be considered and published under the Act. The proposed change to Rule 84 and the forms is being done without reference to any of the rules to which the forms correspond. This, I argue, is a violation of the Enabling Act process."). The Advisory Committee disagreed, noting, "The Committee believes that the publication actually made, with the full opportunity to comment, satisfies the Enabling Act. The opportunity to comment has been seized, as evidenced by the comments received on the Rule 84 proposal." Memorandum from Hon. David G. Campbell, supra, at 112 .

158. Comment from Jonathan Siegel on behalf of 110 Legal Academics 3 (Jan. 31, 2014), available at http://www.asl.edu/Documents/News\%20and\%20Events/2014/Public_Comment_[2014-01-1].pdf ("The Report asserts that '[a] further reason to abrogate Rule 84 is the tension between the pleading forms and emerging pleading standards.' If the 'emerging pleading standards' referred to are the ones emerging from judicial decisions such as Twombly, Iqbal, and their progeny, then this is a polite way of saying that the courts are violating the Federal Rules. If a court dismisses a complaint that Rule 84 declares to be sufficient, the court is necessarily violating the Rules ... . The Forms exist to indicate to judges how simple and brief pleadings can be and to make sure that judges do not wrongly dismiss complaints for being too simple and brief.").

159. Comment from Helen Hershkoff, New York University School of Law; Adam N. Steinman, Seton Hall University School of Law; Lonny Hoffman, University of Houston Law Center; Elizabeth M. Schneider, Brooklyn Law School; Alexander A. Reinert, Benjamin N. Cardozo School of Law; and David L. Shapiro, Harvard Law School 16 (Feb. 5, 2014), available at http://www.afj.org/wpcontent/uploads/2014/02/Professors-Joint-Comment.pdf ("Given that the Committee has yet to take 
support the Advisory Committee's assertion that attorneys do not use the Forms. ${ }^{160}$

In May 2014, the Judicial Conference Committee on Rules of Practice and Procedure approved a package of proposed amendments to the Civil Rules, including a proposed abrogation of Rule 84 and the Appendix of Forms. ${ }^{161}$ The committee stated that, "most of the comments submitted were supportive of the proposal" and that, despite concerns, the Committee "unanimously determined that the publication process and the opportunity to comment on the proposal fully satisfies the Rules Enabling Act." 162 At the time of writing, the proposed amendments and proposed abrogation are under consideration by the Supreme Court. ${ }^{163}$

While the research in this Article was not performed in response to the proposed abrogation of Rule 84, it does provide evidence that attorneys were going far beyond what the Forms required even before Twombly and Iqbal were decided. As will be shown in the next section, pleading additional facts beyond the requirements of a notice pleading standard predated the Twombly or Iqbal decisions.

\section{B. Narrative Pleading Study 1: Methodology and Results}

Auto accident negligence cases provide the clearest application of the drafters' intent concerning the elements of a complaint required to meet the original notice pleading standard, as expressed by the federal forms. Such cases naming a federal defendant typically involve an accident with a federally-owned vehicle performing official duties, such as a postal vehicle. Examination of this narrow case type allows us to compare pleading practices in cases that are likely to be very similar in terms of factual content or changing legal standards. The requirements of the complaint initially filed in federal court should not vary from federal district to district. In addition,

a definitive position on plausibility pleading, striking the Form Complaints commits the Committee to a position that implicitly adopts plausibility pleading as the standard going forward. Abandoning the forms will effectively shut the door on reform of the pleading rules.").

160. Id. ("The Committee's first explanation for why it is abandoning the Forms is based on casual empiricism and self-evident bias. As we understand it, a Subcommittee to study the Forms apparently started with the intuition that lawyers tend not to rely on the Forms, and then conducted an informal survey of undisclosed lawyers - unsurprisingly concluding that their initial intuitions were correct."). The research presented in this Article was prepared independently by researchers at the Federal Judicial Center and not completed at the request of the Advisory Committee.

161. Report from the Comm. on Rules of Practice and Procedure, to Chief Justice of the U.S. and Members of the Judicial Conference of the U.S. 16 (Sept. 2014), available at http://www.uscourts.gov/uscourts/RulesAndPolicies/rules/Reports/ST09-2014.pdf (stating that "after carefully studying the issue, the advisory committee determined that abrogation was the best course.").

162. Id.

163. Id. at 1. Status of the proposed amendments and abrogation was last checked on October 2, 2014. 
we selected these cases to examine the finding by Fairman that simplified notice pleading dominated in the negligence area ${ }^{164}$ and in response to a comment by Miller about the role that Twombly and Iqbal might play in the federal judiciary: "It remains to be seen, however, whether district courts will extend the demands of plausibility pleading to require factual allegations of the elements of relatively uncomplicated civil actions, as exemplified by Official Form 11-formerly Form 9-the paradigm negligence complaint." 165

We examined a random sample of 200 federal automobile accident tort case complaints originally filed in federal court in 2006 (pre-Twombly) in which the United States was the named defendant. ${ }^{166}$ The cases came from 59 different federal districts. We excluded cases that were filed by pro se parties to ensure that such complaints were filed by attorneys who should be aware of the federal notice pleading standard, and cases dismissed for lack of jurisdiction to ensure that the complaints all met acceptable standards for establishing federal jurisdiction. ${ }^{167}$ We downloaded the initial complaints

164. Fairman, supra note 37, at 1047 ("Negligence is the archetypal notice pleading claim. Its elements are basic and well known: duty, breach, causation, and damages. Putting a party on notice of a negligence claim should be just as easy. It is therefore surprising to think that non-notice based pleading requirements might pop up in this area. Nonetheless, they do."). In the end, Fairman concludes that, "Pleading practice in the negligence area thus reflects the pleading model. Simplified notice pleading still dominates." Id. at 1051. In fact, Fairman may have underestimated the extent of non-notice pleading. Fairman examined the pleading practices indirectly by reviewing federal appellate case law and some district court orders resolving motions to dismiss the complaints. Negligence complaints with extensive factual pleading were unlikely to be challenged for an absence of factual support in judicial opinions resolving a motion to dismiss. This study examines pleading practice by directly examining the content of the underlying complaints.

165. Miller, supra note 12 , at 40.

166. Using the Integrated Database file of federal civil cases filed in calendar year 2006, we selected cases based on the following criteria: NOS=350 \& ORIGIN=1 \& FYR=2006 \& PROSE $=0$ \& JURIS $=2$ \& DISP ne 3 (i.e., automobile tort cases (excluding product liability cases, as indicated by the filing attorney on the civil filing cover sheet), originally filed in federal district court in 2006 by a represented plaintiff, naming the United States as a defendant, and not dismissed for lack of jurisdiction).

167. Seven of the 200 cases were excluded from the analysis because the complaint was not available for downloading through PACER, often because the record was sealed. Five of the cases were excluded because they involved circumstances other than the collision of two vehicles, such as injuries arising from an accident allegedly due to negligent maintenance of a road on federal property. 
from PACER for analysis ${ }^{168}$ and created a coding protocol. Inter-coder reliability checks were performed before coding began. ${ }^{169}$

Coders determined whether or not the complaint appeared to follow the more fact-barren Form 11 notice pleading practice or the more fact-inclusive narrative pleading practice. The research design acknowledged that there are "imprecise boundaries" 170 of what courts call notice pleading. ${ }^{171}$ Complaints coded as notice pleading generally contained only the basic factual specificity required by Form 11. Complaints coded as narrative pleading incorporated facts that expand the complaint beyond Form 11 requirements and present a rational narrative that allows the reader to see "paradigms in human stories that help to explain the meaning of those stories." 172 Thus, narrative pleading goes beyond the approach of Form 11 pleading by also

168. Empirical studies of the contents of federal civil complaints as they relate to legal standards are rare. The most similar study we have found are the studies of contents of complaints filed under the PSLRA (See, e.g., A.C. Pritchard \& Hillary A. Sale, What Counts as Fraud? An Empirical Study of Motions to Dismiss Under the Private Securities Litigation Reform Act, 2 J. EMPIRICAL LEGAL STUD. 125, 142 (2005), and the content of patent complaints as they relate to claims of willful infringement patents (See, e.g., Kimberly A. Moore, Empirical Statistics on Willful Patent Infringement, 14 FED. CIR. B.J. 227 (2004)). Boyd and colleagues examined the interrelationship among causes of action in civil complaints to illustrate the relationship of legal claims to one another, the broader composition of lawsuits in trial courts, and the breadth of pleading in individual complaints, but does not attempt to relate these legal claims to changes in legal standards (Christina L. Boyd et al., Building a Taxonomy of Litigation: Clusters of Causes of Action in Federal Complaints, 10 J. Empirical Legal Stud. 253 (2013)). See also Theodore Eisenberg, Section 1983: Doctrinal Foundations and an Empirical Study, 67 CoRNELL L. REv. 482, 524, 535 n.237 (1982) (examination of the contents of complaints in civil rights cases); William Bennett Turner, When Prisoners Sue: A Study of Prisoner Section 1983 Suits in the Federal Courts, 92 HARV. L. REV. 610 (1979) (examining the content of complaints in prisoner civil rights litigation); Margo Schlanger, Inmate Litigation, 116 HARV. L. REV. 1555 (2003) (examining the content of complaints in prisoner civil rights litigation); Theodore Eisenberg \& Stewart Schwab, The Reality of Constitutional Tort Litigation, 72 CORNELL L. REv. 641 (1983) (examining cases in that included a complaint for a constitutional tort filed under Section 1983); David A. Hoffman et al., Docketology, District Courts, and Doctrine, 85 WASH. L. REV. 681 (2007) (finding that formal opinions are rarely written in cases); Matthew Sag, Empirical Studies of Copyright Litigation: Nature of Suit Coding, 100 IowA L. REV. (forthcoming 2014), available at http://ssrn.com/abstract=2330256 (discussing reliance on nature of suit coding in PACER records and providing reference to a working paper by Christopher Cotropia and James Gibson entitled Copyright's Topography: An Empirical Study of Copyright Litigation that examines the importance of using federal dockets in empirical research.).

169. The coders both coded the same sixty complaints, and agreed on the characterization of the complaint as following notice pleading or narrative pleading practice in fifty-seven or $94 \%$ of the cases. Agreement was lower in the secondary coding of types of facts appearing in the narrative pleadings, but still exceeded $70 \%$ in all but the "other" miscellaneous category of facts.

170. Fairman, supra note 37, at 998.

171. The coding standards recognize the impracticality of expecting every complaint to strictly adhere to the bare-bones sufficiency of the notice pleading practice set forth in Form 11. Hence, the coders regarded slight deviations from Form 11 or the incorporation of a few additional facts as still classifying as being within the notice pleading practice. This slight default to notice pleading was expanded even further in Study 2.

172. Elizabeth Fajans \& Mary R. Falk, Untold Stories: Restoring Narrative to Pleading Practice, 15. J. LEGAL WRITING INST. 3, 20 (2009). 
including additional facts that add descriptive color and persuasiveness to the legal arguments. ${ }^{173}$ If a complaint was characterized as narrative pleading, the coders then indicated which of eight types of facts appeared in the complaint. $^{174}$

Overall, the results showed that in 2006 complaints in federal automobile accident cases were already providing many additional facts far beyond what was necessary under Form 11 and the notice pleading standard of Conley. In the 187 analyzed complaints, 172, or 92\%, departed from the notice pleading practice and included additional facts sufficient to define the complaint as representative of narrative pleading. The narrative pleading complaints were also significantly longer than those few complaints that followed the notice pleading model, as would be expected given that the inclusion of additional facts beyond Form 11's requirements would require additional space. The 173 narrative pleading complaints averaged 4.9 pages, while the fourteen notice pleading complaints averaged 3.2 pages. ${ }^{175}$ The shortest complaints for each type were two pages each, while the longest complaint in the sample, one defined as a narrative pleading was twenty-three pages. ${ }^{176}$

The 172 narrative pleading complaints provided a variety of facts. The most common narrative, in 135 , or $72 \%$, of all complaints described facts to establish negligence. For example, the complaint in Manuell v. United States Postal Service exceeded the Form 11 requirements by alleging almost a page of negligence facts such as failing to observe signs and signals, failing to give adequate and timely signal, notice, or warning, and operating without regard to the rights and safety of the plaintiff. ${ }^{177}$ This far exceeded the Form 11 template of "the defendant negligently drove a motor vehicle against the plaintiff." 178

Ninety-one, or $49 \%$, of the complaints included factual details about the accident. While facts about the accident often coincided with facts to establish negligence, as in Manuell, only eighty-three of the complaints included both fact types. Thus, while it is not uncommon for a complaint to

173. Id.

174. The eight types of facts coded in the narrative complaints were: description of plaintiff's injuries, description of plaintiff, description of defendant, accident detail, vehicle descriptions, location of accident, vehicle damage, establishment of negligence, and other.

175. A $t$-test found a significant difference based on complaint type, $t(185)=-2.542, p<.05$. Of course, the large majority of complaints coded in this sample were narrative pleading cases, resulting in a small sample of notice pleading complaints and less possible variability in their complaint lengths.

176. Overall, the average page length was 4.7 pages.

177. Complaint at 4, Manuell v. U.S. Postal Service, No. 1:06-cv-11430-THK (S.D.N.Y. Oct. 27, 2006).

178. See Fed. R. Civ. P. Form 11. One reviewer of this study stated that a long list of template-like negligence claims should not be considered to exceed the requirements of notice pleading. However, as the facts in these cases could easily conform to the Form 11 guidance of "the defendant negligently drove a motor vehicle against the plaintiff," the inclusion of any additional facts should be treated as exceeding those requirements. This issue is further addressed in the second study. 
detail the accident without also extending the description to establish negligence, it is still of note that both fact types go beyond the Form 11 notice pleading requirements.

Ninety-six, or $52 \%$, of the complaints included details about the nature and extent of the injuries allegedly suffered. In Bethey v. United States Postal Service, the complaint alleged that the plaintiff "has sustained injuries including but not limited to left trapezius muscle spasm, lumbar sprain and strain, and cervical sprain and strain, injury to his nervous and muscular systems all of which claims maybe [sic] permanent and cause a serious and permanent impairment of bodily function and emotional and mental distress and may continue to suffer same." ${ }^{\prime 19}$ Again, this exceeded the Form 11 notice pleading requirements.

Eighty-four, or $45 \%$, of complaints also often included vehicle descriptions, and seventy-seven, or $41 \%$, of complaints included information about the specific location of the accident. For example, in Harrington $v$. United States, the complaint alleged that,

Douglas Allen Kopp, an employee of Defendant United States of America acting within the scope of his employment, was driving a 1983 AM General, Model No. M915A1 owned by Defendant also northbound on Interstate 95 in the right lane. As both northbound lanes of Interstate 95 slowed due to bridge construction .... ${ }^{180}$

The complaints on occasion included details of damage sustained by the vehicles, such as "Plaintiff"s vehicle has a smashed-in passenger door and gas leak ...."181 This additional fact type, extent of damage to the vehicles, was found in forty-four, or $24 \%$, of the complaints. All three fact types shown in this complaint exceeded the requirements. Less commonly, some complaints also included descriptions of the plaintiff, in fourteen, or $7 \%$, or defendant, in eight, or $4 \% .^{182}$

Looking across the fifty-nine districts in the random sample, there was no significant difference between districts in whether the pleadings represented notice or narrative pleading, ${ }^{183}$ or any significant differences in

179. Complaint at 3, Bethay v. U.S. Postal Service, No. 2:06-cv-01123 (E.D. Pa. Mar. 15, 2006). Original Form 9 did include the fact that the plaintiff suffered a broken leg. The injuries listed in the 2006 complaints typically offered much more detail regarding the injury. If, however, additional details regarding the nature of the injury are excluded from consideration, $87 \%$ of the complaints still included facts that exceeded those listed in Original Form 9. Approximately $78 \%$ of the complaints included at least two different types of facts that exceeded those listed in Form 11, and $38 \%$ of the complaints included four or more types of facts that exceeded those listed in Form 11.

180. Complaint at 2, Harrington v. United States, No. 4:06-cv-00285 (S.D. Ga. Dec. 5, 2006).

181. Complaint at 3, Brown v. U.S. Postal Service, No. 2:06-cv-7864 (E.D. La. Oct. 11, 2006).

182. For examples of party descriptions, see Complaint, Ferrando v. United States, No. 2:06-cv-433 (D. Az. Feb. 10, 2006).

183. $F(58,186)=.922, p=.63$. 
complaint page length. ${ }^{184}$ This suggests that narrative pleading was widespread across federal judicial districts in 2006 and not just limited to some select districts.

\section{Narrative Pleading Study 2: Methodology and Results}

Upon finding in Study 1 that initial complaints in federal jurisdiction automobile negligence cases included facts beyond those required by Form 11 and notice pleading, we sought to confirm this finding in a related, smaller sample of cases. Responding to a reviewer's comment that complaints in cases brought against the United States likely have more fully developed factual statements in anticipation of the administrative hurdles and levels of review the case will encounter, we selected a second random sample of ninety auto accident tort cases from fifty-seven different federal districts originally filed in federal district courts in 2006, before Twombly, asserting diversity jurisdiction. ${ }^{185}$

We also used Study 2 to respond to a comment at the 2013 Conference on Empirical Legal Studies that we should not consider negligence facts beyond the language presented in the Forms as a reason to classify pleading practice as narrative. The commentator stated that template-like restatements of all of the elements of negligence, with factual support, is a bare bones, rote list that should be considered in line with notice pleading. We disagree and believe that providing negligence facts that exceed the Form requirements should be considered just that - facts exceeding the requirements to promote a narrative, especially when the Form provides specific guidance on wording.

Still, to explore the commenter's suggestion further, in Study 2 we expanded which complaints could be classified as notice pleading. In Study 1 , a complaint was classified as notice pleading if it did not present any of the fact types we explored. In Study 2, a complaint that included additional negligence facts, but no other fact types, would still be classified as notice pleading. ${ }^{186}$ By not including the most common category of additional facts,

184. $F(58,186)=1.01, p=.48$.

185. The comment came to us after our submission of an earlier version of this study to the 2013 Conference on Empirical Legal Studies. As with Study 1, we excluded pro se cases, and cases dismissed for lack of jurisdiction. Using the Integrated Database file of federal civil cases filed in calendar year 2006, we selected cases based on the following criteria: NOS=350 \& ORIGIN=1 \& FYR=2006 \& PROSE $=0$ \& JURIS=4 \& DISP ne 3 (i.e., automobile tort cases, originally filed in federal district court in 2006 by a represented plaintiff, asserting diversity jurisdiction, and not dismissed for lack of jurisdiction). We then downloaded the initial complaints from PACER for analysis. After downloading the cases, we removed cases where the initial complaint was filed in state court and one case where the complaint was not available on PACER.

186. Further limiting what we placed in the narrative pleading practice category, we also removed four cases from being considered narrative pleading that only had negligence facts and the license plate of one or more vehicles. 
we expected that a smaller percentage of complaints ${ }^{187}$ would be classified as narrative pleading practice.

Even with a much stricter definition on what we considered narrative pleading, seventy-two, or $86 \%$, of the eighty-four analyzed complaints departed from the notice pleading practice by including additional facts sufficient to meet our narrative pleading practice definition. This is less than the $92 \%$ found in Study 1, but provides solid evidence that pleading practice did not match Form 11 or notice pleading practice in 2006 in automobile injury cases. Additional facts other than negligence facts were regularly included in the initial complaints.

As in Study 1, the narrative pleading complaints were significantly longer. The seventy-two narrative pleading complaints averaged 5.76 pages, while the twenty notice pleading complaints averaged 2.35 pages. ${ }^{188}$ The page length ranged from two to nineteen pages, with an average page length of 5.5 pages, which was slightly longer than the average page length of 4.7 pages in Study 1. As with Study 1, the complaints did not differ across districts for either whether or not they were classified as narrative pleading ${ }^{189}$ or by page length. ${ }^{190}$ Thus, narrative pleading is common and widespread across districts in both study samples.

\begin{tabular}{|c|c|c|}
\hline \multicolumn{3}{|c|}{ Table 1. Types of Facts in Initial Complaints } \\
\hline Fact Category & $\begin{array}{c}\text { Study 1 } \\
(\boldsymbol{N}=\mathbf{1 8 7})\end{array}$ & $\begin{array}{c}\text { Study 2 } \\
(\boldsymbol{N}=\mathbf{8 4})\end{array}$ \\
\hline $\begin{array}{c}\text { Facts to establish } \\
\text { negligence }\end{array}$ & $135(72 \%)$ & $63(75 \%)$ \\
\hline $\begin{array}{c}\text { Factual details about the } \\
\text { accident }\end{array}$ & $91(49 \%)$ & $46(55 \%)$ \\
\hline $\begin{array}{c}\text { Details about the nature } \\
\text { and extent of injuries }\end{array}$ & $96(52 \%)$ & $44(53 \%)$ \\
\hline Vehicle descriptions & $84(45 \%)$ & $39(46 \%)$ \\
\hline Location of accident & $77(41 \%)$ & $26(31 \%)$ \\
\hline Damage to vehicles & $44(24 \%)$ & $3(4 \%)$ \\
\hline Descriptions of plaintiff & $14(7 \%)$ & $9(11 \%)$ \\
\hline Descriptions of defendant & $8(4 \%)$ & $9(11 \%)$ \\
\hline
\end{tabular}

187. This would also take into account the smaller number of cases examined in Study 2.

188. A $t$-test was used to determine that the groups significantly differed from each other, $t(90)=$ $-4.52, p<.001$.

189. $F(56,91)=.75, p=.84$.

190. $F(56,91)=1.30, p=.21$. 
Table 1 provides a comparison of the number and percentage of initial complaints in each study that included facts for each of the studied categories. There is strong agreement across the two studies, with similar percentages of complaints in each study including facts to establish negligence, details about the accident, details about the nature and extent of injuries, vehicle descriptions, and descriptions of the plaintiff. The results in the two studies significantly differed only such that complaints in Study 2 were less likely to include facts about specific vehicle damage, ${ }^{191}$ and complaints in Study 1 were less likely to include descriptions of the defendant. ${ }^{192}$ Otherwise, the occurrence of fact types did not significantly differ between the studies. This warrants additional discussion into why this type of complaint, when the United States is a party, more often includes vehicle descriptions and less often describes the defendant.

\section{DISCUSSION OF THE RESULTS}

The results were far more convincing than we expected. When we began, we intended to determine the extent to which Twombly and Iqbal transformed pleading practices (if at all) from the notice pleading model in Conley and exemplified by Form 11 (previously Form 9) to a more fact-based model of narrative pleading. Earlier studies found that while fact-based pleading was common in more complex cases, "simplified notice pleading still dominates" in negligence cases and reflected the Form 9/11 pleading model, though pleading practice had not been examined with the same experimental rigor. ${ }^{193}$

We expected to find fact-based pleading in fewer than half of the cases filed in 2006, and intended to then look at similar complaints after Iqbal to assess any change in movement toward fact-based pleading. Instead, we found that prior to Twombly complaints in simple automobile accident negligence cases were rich with facts that far exceeded the requirements of Form 11 . With more than $90 \%$ of these cases including facts that exceeded the guidance of Form 11, we saw no need to examine post-Iqbal pleading

191. $t(32.6)=5.24, p<.001$.

192. $t(14.5)=-2.22, p<.05$.

193. Fairman, supra note 37, at 1051; See DODSON, supra note 23, at 132-33 ("The beautiful simplicity of the Federal Forms has never been a reliable model. Few filed complaints are as Spartan."). As support for arguing that it is a myth that "plaintiffs plead barebones complaints," Dodson cited Ettie Ward, The After-Shocks of Twombly: Will We "Notice" Pleading Changes?, 82 ST. JOHN's L. REv. 893, 899 (2008). Ward, in turn, cited the earlier review by Fairman, supra note 37. At the time of Fairman's review, his study of federal case law suggested that notice pleading was a myth, but not in negligence such as those examined here. Of course, Fairman focused on pleading standards and not pleading practice and so there is a chance that pleading practice in negligence cases had already shifted away from notice pleading practice before his review. If so, this only strengthens the argument that Twombly and Iqbal did not cause the shift from notice pleading to narrative pleading practice. 
practice to determine if notice pleading died with Twombly and Iqbal. We encourage others to replicate our findings in other case types and to perform before and after comparisons.

An anonymous reviewer of an earlier draft of this paper remarked, "[N]o one has thought that federal complaints typically look like Form 9/11." This argument provides additional support that, even when the Supreme Court supported the notice pleading standard, pleading practice had already shifted to narrative pleading before Twombly and Iqbal were decided. As shown in Part IV, the infrequency of notice pleading and pervasiveness of narrative pleading prior to Twombly, even in simple automobile accident cases, supports the notion that notice pleading may have yielded to narrative pleading decades ago, if it existed in any meaningful form at all. Those who believe that Twombly and Iqbal killed notice pleading practice should first demonstrate that there was a period since the adoption of the Federal Rules when pleading practice met (but did not exceed) the notice pleading standard requirements, or acknowledge that the practice might have only existed in spirit, despite support for the pleading standard.

Narrative pleading prior to Twombly may explain why most empirical studies show that there is only a modest, if any, increase in the likelihood that motions to dismiss were ultimately granted and cases dismissed after Iqbal. ${ }^{194}$ If litigants were already pleading more facts to support a narrative pleading, a new, heightened standard requiring them to plead facts showing a claim is plausible would not be a dramatic shift in practice. In different types of cases, "more or less description may be inherent" 195 to provide a general description called for under notice pleading standards. In practice, the findings of this study might support the conclusion expressed in a memorandum to the Advisory Committee on Civil Rules and the Judicial Conference Standing Rules Committee on Rules of Practice and Procedure: "The approach taken by many courts may suggest that Twombly and Iqbal are providing a new framework in which to analyze familiar pleading concepts, rather than an entirely new pleading standard." 196 The Supreme

194. Another possible explanation for the modest change in grant rates is that changes in the litigation and settlement strategies of plaintiffs may have shifted the mix of cases so that grant rate alone is a misleading indicator of the effects of Twombly and Iqbal. Hubbard's close examination of the outcome of cases filed before Twombly and decided after Twombly revealed no evidence of such a selection effect due to Twombly. See also Hubbard, supra note 11 ("I find that Twombly precipitated no significant change in dismissal rates, even after accounting for selection effects."). But see GELBACH, supra note 17, for an elaboration of this concern involving analysis of selection effects and grant rates following Iqbal.

195. Fairman, supra note 37, at 1001.

196. Memorandum from Andrea Kuperman, Rules Law Clerk to J. Lee H. Rosenthal, to Civil Rules Comm. and Standing Rules Comm. 5 (Dec. 15, 2010), available at http://www.uscourts.gov/uscourts/rulesandpolicies/rules/iqbal_memo_121510.pdf. 
Court decisions might just have been "the latest steps in a long-term trend that has favored increasingly early case disposition." 197

\section{A. Discussion of the Federal Rules}

Over the past three decades, Federal Rules amendments might have had an incidental effect of encouraging narrative pleading, with the inclusion of the factual circumstances of the case to achieve other purposes. Movement toward a more active role for judges in the pretrial stages of litigation requires judges to obtain an early awareness of the underlying facts of the case, and such facts are now often presented as part of the pleadings to inform the judges of circumstances that may be relevant to early case management decisions.

\section{Federal Rules Changes and Pleading Practice}

The clearest example of Federal Rules amendments driving factual pleading is the amendment of Rule 16 in 1983 and 1993, allowing judges to convene an early pretrial conference to resolve preliminary issues and to prepare a schedule for litigation that is suited to the issues in the case. ${ }^{198}$ Rule 16(b)(2) requires the court to issue a scheduling order within 120 days after the complaint is served on the defendant. ${ }^{199}$ Rule 16(b)(3) indicates that the scheduling order must include a schedule for amendment of pleadings and completion of discovery, among other things. ${ }^{200}$ In order to obtain the information necessary to develop such a scheduling order, Rule 16(c)(2) allows the judge to convene a pretrial conference. ${ }^{201}$

197. Miller, supra note 5, at 9,10 ("today's civil litigation is neither civil nor litigation as previously known.").

198. For a discussion of the evolution of recommendations regarding judicial management of pretrial proceedings presented in the original Manual for Complex Litigation (1968) into the 1983 amendments to Federal Rule 16 authorizing more assertive judicial management of pretrial stages of litigation, see Miller, supra note 5, at 294-95.

199. FED. R. CIV. P. 16(b)(2).

200. FED. R. CIV. P. 16(b)(3).

201. Among the issues the court may consider at such an initial conference are:

(A) formulating and simplifying the issues, and eliminating frivolous claims or defenses;

(B) amending the pleadings if necessary or desirable;

(C) obtaining admissions and stipulations about facts and documents to avoid unnecessary proof, and ruling in advance on the admissibility of evidence;

(F) controlling and scheduling discovery, including orders affecting disclosures and discovery under Rule 26 and Rules 29 through 37;

(G) identifying witnesses and documents, scheduling the filing and exchange of any pretrial briefs, and setting dates for further conferences and for trial

(P) facilitating in other ways the just, speedy, and inexpensive disposition of the action FED. R. CIV. P. 16(c)(2). 
Judicial consideration of such issues at an early litigation stage has prodded plaintiffs to include sufficient facts in the complaint to allow them to defend their litigation strategies at the initial pretrial conference. ${ }^{202}$ By providing an extensive account of the factual circumstances that underlie the claims in the complaint itself, the plaintiff then will inform the judge of the narrative that the attorney intends to present and the role of such facts in supporting the claims.

Amendments of civil rules to control abuses of litigation have also resulted in a greater emphasis on fact pleading. For example, in 1983 and again in 1993, Rule 11 was amended to impose a clearer duty on attorneys to undertake a factual investigation of the basis of pleadings prior to filing. ${ }^{203}$ The possibility of being sanctioned by the court, including possible payment of costs and attorney fees, for filing an improper pleading can encourage attorneys to include more facts in the complaint in order to demonstrate that they had undertaken a proper investigation. ${ }^{204}$

Furthermore, since 1938, there have been at least ten amendments to Rule 26. The 1993 and 2000 amendments to Rule 26(a) encouraged earlier disclosure of factual information by the parties, and some of this disclosure may take place as part of the pleadings. Under Rule 26(a), parties must disclose information that would appear to far exceed what is required by the notice pleading standard. ${ }^{205}$ The 2000 amendments to Rule 26(b) narrowed

202. Related amendments to Rule 26(f) require the attorneys to meet and confer prior to the initial Rule 16 scheduling conference to "consider the nature and basis of their claims and defenses and the possibilities for promptly settling or resolving the case; make or arrange for the disclosures required by Rule 26(a)(1); discuss any issues about preserving discoverable information; and develop a proposed discovery plan.” FED R. CIV. P. 26(f)(2). The need to disclose information necessary to develop such a discovery plan also encourages the plaintiff to disclose facts related to the underlying claims in the case. This was especially true from 1993 to 2000, when Rule 26(a)(1) required initial disclosure only with regard to "disputed facts alleged with particularity in the pleadings". FED. R. CIV. P. 26(a)(1).

203. Attorneys are now required to certify that each filing:

(1) [] is not being presented for any improper purpose, such as to harass, cause unnecessary delay, or needlessly increase the cost of litigation;

(2) the claims, defenses, and other legal contentions are warranted by existing law or by a nonfrivolous argument for extending, modifying, or reversing existing law or for establishing new law;

(3) the factual contentions have evidentiary support or, if specifically so identified, will likely have evidentiary support after a reasonable opportunity for further investigation or discovery; and

(4) the denials of factual contentions are warranted on the evidence or, if specifically so identified, are reasonably based on belief or a lack of information.

FED. R. CIV. P. 11(b).

204. This was especially true following the 1983 amendments to Rule 11, which allowed a greater opportunity for sanctions than the 1993 amendment. See generally Stephen B. Burbank, The Transformation of American Civil Procedure: The Example of Rule 11, 137 U. PA. L. REV. 925 (1989). See also Ellis \& Shah, supra note 13, at 69-70.

205. Parties must disclose to the opposing party, without waiting for a request, "the name and, if known, the address and telephone number of each individual likely to have discoverable information- 
the scope of discovery as a matter of right from material relevant to the "subject matter" of the litigation to material relevant to the claims and defenses raised in the litigation. ${ }^{206}$ These amendments encouraged the plaintiffs to include more specific claims in the complaint in order to retain a broad scope of discovery, and thereby might have resulted in complaints that include greater factual specificity regarding the nature of the litigation.

Combined, the increased emphasis on early disclosure of detailed information, including the factual foundations for the claim, and restricting discovery to the claims and defenses raised in the litigation might result in litigants including more such information in the complaint, along with factual support. ${ }^{207}$ With proposed amendments to the Civil Rules, including changes to Rules 16 and 26, recently approved by the Committee on Rules of Practice and Procedure, ${ }^{208}$ research should address how these changes, if implemented, could further affect federal pleading practice. Proposed changes to Rule 26, for example, would narrow the scope of discovery, which led to some of the most vocal opposition when the rules package was submitted for public comment.

\section{Discovery and Pleading Standards}

Heightened pleading standards have been regarded as a response to, and remedy for, escalating discovery costs. In 1987, Judge Easterbrook stated that, regarding judicial supervision of the discovery process, "the judicial

along with the subjects of that information - that the disclosing party may use to support its claims or defenses, unless the use would be solely for impeachment." FED. R. CIV. P. 26(a)(1)(A)(i). Under Rule 26(a)(3),

[A] party must provide to the other parties and promptly file the following information about the evidence that it may present at trial other than solely for impeachment: (i) the name and, if not previously provided, the address and telephone number of each witness - separately identifying those the party expects to present and those it may call if the need arises;

(ii) the designation of those witnesses whose testimony the party expects to present by deposition and, if not taken stenographically, a transcript of the pertinent parts of the deposition; and

(iii) an identification of each document or other exhibit, including summaries of other evidence - separately identifying those items the party expects to offer and those it may offer if the need arises.

FED. R. CIV. P. 26(a)(3). The 1993 amendments to Rule 26(a), establishing the duty to disclose, were more expansive to require identification of potential evidence "relevant to disputed facts alleged with particularity in the pleadings." This requirement would have encouraged parties to include greater factual detail in the complaint. The 2000 amendments narrowed the breadth of this initial disclosure requirement to include identification of witnesses and documents "that the disclosing party may use to support its claims and defenses."

206. FED. R. CIV. P. 26(b)(1).

207. These emphases also likely set the stage for the Twombly and Iqbal decisions. See Sullivan, supra note 23 , at 56 .

208. Report from the Comm. on Rules of Practice and Procedure, supra note 161, at 13-18. 
officer always knows less than the parties, and the parties themselves may not know very well where they are going or what they expect to find."209 Heightened pleading standards may be particularly attractive in cases where the claim "is easy to allege yet risks voluminous discovery," 210 especially when an earlier dismissal at the pleading stage could conserve resources. ${ }^{211}$ The Supreme Court endorsed this view, stating in Twombly that the new standard would protect against the costs of burdensome discovery. ${ }^{212}$

Judge Ellis noted that the Twombly and Iqbal decisions "are inseparable from their underlying supposition that dramatic increases in the cost of litigation [,] and especially discovery [,] justified the judicial imposition of more rigorous pleading requirements." ${ }^{213}$ With these new requirements, "federal judges are now supposed to act as gatekeepers to discovery, and the plausible pleading standard is supposed to be their tool to do so."214 Some judges have been cautious. After considering the interaction of Twombly/Iqbal and "the discovery problem" Judge Sullivan warned that "Problems cry out for solutions, but solutions often create newer and bigger problems." 215

While reducing discovery costs is an admirable goal, such costs are rarely an issue in the federal negligence motor vehicle cases in this present study. These cases are among the simpler types of federal cases and rarely involve extensive discovery. ${ }^{216}$ Apart from medical records and insurance information, for example, the opportunity for discovery would seem quite limited. If pleading practice in these simpler cases has departed from notice pleading standards, the reason cannot be just a need to guard against needless expense and delay arising from abuse of discovery. The departure from notice pleading in these cases must be in response to other concerns.

209. Frank H. Easterbrook, Discovery as Abuse, 69 B.U. L. Rev. 635, 638 (1989).

210. Id. at 1060. But see A. Benjamin Spencer, Pleading and Access to Civil Justice: A Response to Twiqbal Apologists, 60 UCLA L. REV. 1710, 1714 (2013) (discussing three different groups of what Spencer calls "apologists," people who he claims defend the Twombly and Iqbal decisions because they either (a) find it consistent with previous standards, (b) argue that it did not make a substantial impact on federal pleading practice, or (c) laud the decision as a response to escalating discovery costs. Regarding the third category, Spencer also states that discovery abuse "has not been confirmed to exist").

211. Fairman, supra note 37, at 1014.

212. Bell Atl. Corp. v. Twombly, 550 U.S. 544, 558-59 (2007).

213. Ellis \& Shah, supra note 13, at 66.

214. Fitzpatrick, supra note 115, at 1629.

215. Hon. John P. Sullivan, Do the New Pleading Standards Set Out in Twombly and Iqbal Meet the Needs of the Replica Jurisdictions?, 47 SUFFOLK U. L. REV. 53, 53 (2014).

216. E. Donald Elliott, Twombly in Context: Why Federal Rule of Civil Procedure $4(b)$ is Unconstitutional, 64 FLA. L. REV. 895, 908 n.53 (2012) ("When the rules were adopted in 1938, most cases involved simple historical facts, such as an automobile accident, for which discovery was self-limited by the nature of the facts in controversy."). 


\section{B. Narrative Pleading}

The data above indicate that pleading practice already gravitated toward fact-rich complaints before the Twombly and Iqbal decisions. But why does this matter? Does the presence of a fact-rich complaint affect the way in which judges consider and decide a motion to dismiss? Conceivably, a judge may choose to ignore such facts for purposes of resolving a motion to dismiss and rely solely on whether the complaint meets the notice pleading requirement. We contend, however, that judges do rely on the information presented and that psychological research can help explain how that additional information is used. In this section we describe the characteristics of narrative pleading practice and how it relates to resolving motions to dismiss under the Conley standard and the Twombly/Iqbal standard. We believe that before Twombly judges had already come to expect complaints with additional facts and that these facts present a narrative that can affect decisions regarding whether a complaint should survive a 12(b)(6) motion.

"Narrative pervades the law." 217 Narratives, however, can be both a help and a hindrance to decision makers. Put simply, narrative pleading involves including additional facts to tell a more complete story in the complaint. The use of narratives is a way to present experiences so they are more comprehensible and more easily processed. ${ }^{218}$ "Traditional stories are full of regularities" and people incorporate "such regularities into a story schema and make use of them during processing." 219 By relying on similarities between stories, people organize their many experiences into narratives that they then rely on when examining a situation. ${ }^{220}$ In this manner, a narrative within a complaint can affect how a judge reviews a civil complaint.

Narrative pleading is akin to the Story Model, which posits that juror comprehension and performance will improve when jurors create a narrative story to organize all of the information that they receive during a trial. ${ }^{221}$

217. Anne E. Ralph, Not the Same Old Story: Using Narrative Theory to Understand and Overcome the Plausibility Pleading Standard, 26 YAle J.L. \& Human. 1, 33 (2014) (citing Peter Brooks, Narrative in and of the Law, in A COMPANION TO NARRATIVE THEORY 415, 416 (James Phelan \& Peter J. Rabinowitz eds., 2005). Ralph provides an excellent summary of narrative theory, the characteristics of a narrative, and their relationship to the plausibility standard.

218. Id. at 25-26.

219. JeAn Matter MANDler, Stories, SCRIPTS, AND SCENES: AsPeCts of SChema Theory, at $x$ (Psychology Press 2014) (1984).

220. Ralph, supra note 217, at 26 (citing Jennifer Sheppard, Once Upon a Time, Happily Ever After, and In a Galaxy Far, Far Away: Using Narrative to Fill the Cognitive Gap Left by Overreliance on Pure Logic in Appellate Briefs and Motion Memoranda, 46 WiLlametTe L. ReV. 255, 260 (2009)).

221. See Nancy Pennington and Reid Hastie, A Cognitive Theory of Juror Decision Making: The Story Model, 13 CARdozo L. ReV. 5001 (1991); Nancy Pennington and Reid Hastie, Explaining the Evidence: Tests of the Story Model for Juror Decision Making, 62 J. PERS. \& SOC. PSY. 2, 189 (1992). 
According to the Story Model, the juror will choose the case that is the most coherent, which often means choosing the story that is the most plausible and complete and without unexplained gaps and inconsistencies in the evidence. ${ }^{222}$ The same can be said for judges. Fact-rich claims are likely to be more complete and should offer a coherent and plausible re-telling of the events leading to the case. Of course, a fact-rich complaint is not the same thing as a complaint that survives a 12 (b)(6) motion. ${ }^{223}$ Still, it is a natural instinct to use all available information in its current format to construct a coherent account and not expend additional effort ignoring information that contributes to that account. ${ }^{224}$ The problems inherent in relying on these instincts likely existed before Twombly but were likely exacerbated after Iqbal, with judges relying on judicial experience and common sense when reviewing complaints deciding on motions to dismiss.

The goal of the complaint is to simplify the case into a cohesive narrative that clearly explains why the plaintiff deserves their prayer for relief. As stated by Ralph, "[O]ne way to enhance plausibility through the use of narrative is to include greater factual detail." 225 Taleb referred to a similar cognitive process as the narrative fallacy. ${ }^{226} \mathrm{He}$ describes the fallacy partially as "our predilection for compact stories over raw truths" because information is costly to obtain, to manipulate, and to retrieve. ${ }^{227}$ This is especially true of litigation where the cost of obtaining sufficient information to survive a motion to dismiss can be high. ${ }^{228}$

222. Dan Simon, A Psychological Model of Judicial Decision Making, 30 RUTGERS L.J. 1, 29 (1998) (citing Nancy Pennington \& Reid Hastie, Reasoning in Explanation-Based Decision Making, in REASONING AND DECISION MAKING 123 (Philip Nicholas Johnson-Laird \& Eldar Shafir eds., 1994)).

223. For example, see Ralph, supra note 217, at 50-52 (citing Complaint and Jury Demand, HDC, LLC v. City of Ann Arbor, No. 09-14027, 2010 WL 2232220 (E.D. Mich. May 27, 2010), aff'd 675 F.3d 608 (6th Cir. 2012).

224. Barbara A. Mellers, A. Schwartz \& A.D.J. Cooke, Judgment and Decision Making, 49 ANN. REv. PSYCHOL. 447, 455 (1998). This has also been referred to as the concreteness principle, which would find it unlikely that a judge would transform a narrative pleading complaint into a notice pleading complaint when deciding on a 12(b)(6) motion. See Paul Slovic, From Shakespeare to Simon: Speculations-And Some Evidence-About Man's Ability to Process Information, 12 OR. RES. INST. BULL. 1 (1972).

225. Ralph, supra note 217, at 35.

226. Nassim Nicholas Taleb, The Black Swan: The Impact of the Highly Improbable 62-84 (2007) ("The narrative fallacy addresses our limited ability to look at sequences of facts without weaving an explanation into them, or, equivalently, forcing a logical link, an arrow of relationship, upon them. Explanations bind facts together. The make them all the more easily remembered; they help them make more sense. Where this propensity can go wrong is when it increases our impression of understanding." Id. at 64 (emphasis in original)).

227. Id. at 68 .

228. Emery G. Lee III \& Thomas E. Willging, Fed. Judicial Ctr., Litigation Costs in Civil CASES: Multivariate ANALysis, RePort to THE JUdiCIAL CONFERENCE ADVISORY COMMITTEE ON CIVIL RULES, (Mar. 2010), available at http://www.fjc.gov/public/pdf.nsf/lookup/ costciv1.pdf/\$file/costciv1.pdf; see also Emery G. Lee III \& Thomas E. Willging, Defining the Problem of Cost in Federal Civil Litigation, 60 DuKE L.J. 765 (2010). 
The desire to create stories out of facts stems from how the brain processes information. ${ }^{229}$ A clear, cohesive narrative can enhance a decision maker's ability to see causation between the presented elements and make the described events "more easily remembered . . . and make more sense."230 If the use of narrative can affect causal judgments, it is easy to see how narrative pleading can have an effect on how judges consider negligence cases. Ralph suggests that "greater awareness of narrative theory and greater reliance on narrative techniques can help litigants and judges understand and comply with the plausibility standard." 231 However, Ralph's article appears to assume that narrative pleading is a novel way to respond to Twombly and Iqbal, rather than a pleading practice that was already common before those cases. Narrative pleading is not new. In addition, while Ralph presents an impressive review of narrative pleading and the law, she does not acknowledge many of the concerns presented by Taleb and others regarding the use of narratives and schemas.

\section{Decision Making Concerns}

"Good judgment requires an analysis of content, in addition to laws, principles, and axioms." 232 We have shown that the content of complaints resembled narrative pleading before Iqbal. In this section, we now argue that problems associated with this additional information could change how a judge considers a motion to dismiss, regardless of whether she uses a notice pleading or plausibility pleading standard. ${ }^{233}$

The narrative format presents judges with far more information than the bare bones notice pleading of Form 11 . When faced with a fact-rich narrative, the Conley test, which asks if the plaintiff can prove any set of facts in support of his claim, makes little sense. The judge need not imagine such a set of facts; the facts that will be relied on have already been set forth to meet the early information requirements of the Federal Rules. The proffer of such facts invites the judge to become more involved earlier in structuring the litigation, as intended by the Rule 16 amendments. In developing a scheduling order for amendment of pleadings and completion of discovery,

229. TALEB, supra note 226 , at $68-69$. Taleb refers to the idea that the more you summarize information, the more ordered it becomes, and, accordingly, the less random, as "Andrey Nikolayevich's Rule" and noted that "myths impart order to the disorder of human perception." Id. at 69. For the seminal book on the psychology of decision making and heuristics, see JUDGMENT UNDER UNCERTAINTY: HeURISTICS \& BiASES (Daniel Kahneman, Amos Tversky \& Paul Slovic eds., 1982).

230. TALEB, supra note 226, at 64 .

231. Ralph, supra note 217 , at 2 .

232. Mellers, Schwartz \& Cooke, supra note 224, at 450 (citing research from Gerd Gigerenzer).

233. While the additional facts can lead to the decision making errors described in this section and while we believe that these errors existed long before Twombly and Iqbal, we also believe that the plausibility standard exacerbates the likelihood of these errors due to a new, undefined reliance on judicial experience and common sense. 
the judge will become familiar with the strengths and weaknesses of the plaintiff's case. Any preliminary disputes over the breadth of proposed discovery also will require close consideration of the factual basis of claims presented in the complaint. Accordingly, the additional information that comes along with narrative pleading practice presents a judge with a very different, and more complex, decision making context than the one anticipated by Conley.

Research by Kahneman and Tversky, among others, has demonstrated that human judgments cannot be properly understood without taking into account the context or "frames" in which the judgment is made. ${ }^{234}$ In this instance, the decision task regarding whether the complaint should be dismissed for failure to state a claim is very different when presented with a fact-rich narrative complaint, even if the Conley "any set of facts" notice pleading standard remains. Research about human decision making indicates that it is unreasonable to expect judges to ignore what they have learned about a case from a fact-rich narrative pleading, and try to imagine if there may be some alternative set of facts that would provide proper support for the plaintiff's claim. With narrative pleading and additional facts, judges will attempt to make the most informed decision based on the available information, resulting in a different decision process, even under the traditional notice pleading standard.

With the advent of the plausibility pleading standard, the Supreme Court may have inadvertently created additional problems for judicial decision making. Judges have always faced potential decision making errors (heuristics ${ }^{235}$ ) when deciding motions to dismiss. By inviting judges to rely on their "judicial experience and common sense" 236 the Supreme Court encouraged reliance on factors that may differ greatly across judges, thereby creating potential inconsistencies in the application of pleading standards. Moreover, judges' experience and common sense are "highly subjective concepts largely devoid of accepted - let alone universal-meaning."237 When the terminology cannot be consistently defined, judges' interpretations will almost always vary. One would expect that "reasonable judges could

234. Amos Tversky \& Daniel Kahneman, The Framing of Decisions and the Psychology of Choice, 211 SCI. 453 (1981); see also Ian K. Belton, Mary Thomson \& Mandeep K. Dhami, Lawyer and Nonlawyer Susceptibility to Framing Effects in Out-of-Court Civil Litigation Settlement, $11 \mathrm{~J}$. EMPIRICAL LEGAL STUD. 578 (2014).

235. See JUdGMENT UNDER UNCERTAINTY: HEURISTICS \& BIASES, supra note 229.

236. Ashcroft v. Iqbal, 556 U.S. 662 (2009).

237. Access to Justice Denied: Hearing on Ashcroft v. Iqbal Before the Subcomm. on the Constitution, Civil Rights, and Civil Liberties of the H. Comm. on the Judiciary, 111th Cong. 9 (2009) (statement of Arthur M. Miller), available at http://judiciary.house.gov/hearings/pdf/Miller091027.pdf. 
disagree" ${ }^{238}$ when using their own experience and common sense, and this could result in inconsistent decisions, despite any best intentions. ${ }^{239}$

Twombly and Iqbal encourage judges to search for gaps and to assess the plausibility of the narrative by relying, in part, on their judicial experience and common sense. A more fact-rich complaint offers additional information to allow the creation of a coherent narrative. Greater factual detail may benefit the plaintiff when the judge considers whether the plaintiff's complaint states a claim. However, providing additional information does not necessarily lead to better decision making. For example, narrative complaints might be, by their very nature, intended to bias a decision maker. As stated by Gewirtz, "[T]he goal of storytelling in law is to persuade an official decision maker that one's story is true, to win the case . . ."240 Adding additional facts to initial complaints beyond the notice pleading standard might be in response to changes in the Federal Rules, but they also respond to the psychological expectation that fully telling your story is a persuasive tool to be used by attorneys. The remainder of this section will present a selection of cognitive biases that might affect judicial decision making and examine their relationship to narrative pleading. ${ }^{241}$

Mental shortcuts, such as creating a narrative or relying on the more readily available information, can improve the efficiency of information storage and retrieval. ${ }^{242}$ As stated by Taleb, "compression is vital to the performance of conscious work." ${ }^{433}$ However, compression and mental shortcuts can also lead to decision making errors.

238. Sullivan, supra note 215 , at 80 .

239. Through all of this discussion of decision making errors, it is important to note, as stated by Reinert, that discussions about whether judges are able to make the difficult decision of whether something meets the pleading standard "is not made to denigrate judges." Reinert, 162 U. PA. L. REV., supra note 15 , at 1769. Instead, judges, like all people, face limitations in how much information can be processed and how to do so most effectively. Id. (Reinert's article focuses on plausibility pleading, but the psychological principles underlying his analysis also generally apply to decision making in the broader motion to dismiss context.).

240. Ralph, supra note 217, at 35 (quoting Paul Gewirtz, Narrative and Rhetoric in Law, in LaW's StORIES: NARRATIVE AND RHETORIC IN LAW 2, 5 (Paul Gewirtz \& Peter Brooks eds., 1996).

241. Determining how judges analyze the often-complex filings before them and what affects their decision making is worthy of many articles and outside the primary purpose of this one. For an excellent review, see Richard A. Posner, How Judges Think (Harvard Univ. Press 2010). Empirical research also continues to address this complicated issue. For a recent example, see M. Todd Henderson and William H.J. Hubbard, Do Judges Follow the Law? An Empirical Test of Congressional Control Over Judicial Behavior (Coase-Sandor Inst. for Law and Econ. Working Paper No. 671, 2014), available at http://chicagounbound.uchicago.edu/cgi/ viewcontent.cgi?article $=1665 \&$ context=law_and_economics (finding that judges made a required certification that attorneys complied with F.R.C.P. Rule 11(b) in less than fourteen cases of cases in which these certifications were legally required).

242. Amos Tversky \& Daniel Kahneman, Availability: A Heuristic for Judging Frequency and Probability, 5 COGNITIVE PSYCHOL. 1, 207 (1973).

243. TALEB, supra note 226, at 68. 
In responding to pleadings, judges may be vulnerable to the confirmation bias, which occurs when someone interprets available information in a manner that is consistent with prior beliefs or expectations. ${ }^{244}$ A prevalent theme in critical thinking research and an important skill for judges is "to be able to decouple . . . prior beliefs and opinions from the evaluation of evidence and arguments." 245 When presented with an initial complaint, a judge's prior beliefs could unknowingly influence how he or she perceives the case. Not only are people biased toward confirming their prior beliefs, they also have a difficult time evaluating conclusions that are inconsistent with those beliefs. ${ }^{246}$ Additionally, recent research found that this bias does not correspond with intelligence or cognitive ability, ${ }^{247}$ so even the most intelligent decision makers might find himself or herself relying inappropriately on their earlier beliefs. $^{248}$

Another cognitive bias that warrants consideration is the availability heuristic, in which decision makers associate the likelihood of the probability of an event with how easily an example comes to mind. ${ }^{249}$ For example, a judge reading a complaint in an automobile accident case might wonder how similar cases were resolved and base her assessment of the complaint on the likelihood of success on the most easily recalled similar case. Closely related to the availability heuristic is the simulation heuristic. Those using the simulation heuristic also rely on the mental accessibility of an event but do so to replace an unexpected event with a normal one when thinking counterfactually. ${ }^{250}$ For example, a judge presented with a complaint detailing how the driver of a postal truck sped through a stop sign and struck a pedestrian might wonder "what if the driver had stopped?" Such a question

244. Raymond S. Nickerson, Confirmation Bias: A Ubiquitous Phenomenon in Many Guises, 2 Rev. GEN. PSYCHOL. 175 (1998). Some researchers refer to the similar phenomenon as myside bias. For this Article, we consider both terms as confirmation bias.

245. Keith E. Stanovich \& Richard F. West, Natural Myside Bias Is Independent of Cognitive Ability, 13 THINKING \& REASONING 225, 225-26 (2007) (presenting an extensive literature review of research on such critical thinking skills and the effects of myside (confirmation) bias).

246. $I d$.

247. See Keith E. Stanovich, Richard F. West \& Maggie E. Toplak, Myside Bias, Rational Thinking, and Intelligence, 22 CURRENT DiRECTIONS IN PSYCHOL. SCI. 259 (2013); see also Stanovich \& West, supra note 245, at 226-27 (also presenting research that found a moderate correlation between cognitive ability and the ability to escape the bias).

248. Reinert also notes that "because many judges believe themselves to be even more objective than their average colleague (a mathematical impossibility), judges are particularly vulnerable to such biases." Reinert, 162 U. PA. L. REV., supra note 15, at 1789 (citing Jerry Kang et al., Implicit Bias in the Courtroom, 59 UCLA L. REV. 1124, 1128-32 (2012).

249. See Tversky and Kahneman, supra note 242, at 207; see also Shari S. Diamond and Loretta J. Stalans, The Myth of Judicial Leniency in Sentencing, 7 BEHAV. SCI. \& L. 73 (1989).

250. Daniel Kahneman \& Amos Tversky, The Simulation Heuristic, in JUdGMENT UndER UnCERTAINTY: Heuristics AND BIASES (Daniel Kahneman, Paul Slovic \& Amos Tversky eds., 1998). 
could affect how the judge pieces together the narrative underlying the case. $^{251}$

Combined, confirmation bias and the availability and simulation heuristics are likely present when deciding under a notice pleading standard but even more of a concern with the plausibility pleading standard. Plausibility pleading, which invites judges to rely on their own experience and common sense, may leave judges more vulnerable to such decision making biases when considering a motion to dismiss. Judges have different judicial experiences and, accordingly, these differential experiences could lead to inconsistencies in how they apply their judicial experience when considering motions to dismiss. In his recent article, Reinert argues that judges might not be able to rely on their own judicial experience and could be vulnerable to cognitive biases when making decisions. ${ }^{252}$ Reinert cites the significant decrease in the number of trials, growth of alternative dispute resolution procedures, confidential settlement agreements, and protective orders keeping discovery confidential as reasons why judges are unable to easily compare an instant case to their prior experiences. ${ }^{253}$ If judges are seeing fewer trials and settlement agreements are not disclosed, the judge will have less experience on which to base his or her plausibility assessment. With less relatable information, judges might become increasingly vulnerable to errors in decision making. ${ }^{254}$

However, the solution is not to provide judges with more information. As stated by Taleb, "The more information you give someone, the more hypotheses they will formulate along the way, and the worse off they will be. They see more random noise and mistake it for information." 255 Once someone obtains the minimum information necessary to make a decision, additional information does not improve the accuracy of a judgment, only a

251. For the seminal review of counterfactual thinking, see Neal Roese, Counterfactual Thinking, 121 PSYCHOL. BuLl.1, 133 (1997). One of the authors performed an experimental study on how mock jurors use counterfactual thinking when making negligence verdicts and found that such thoughts come automatically and are heavily relied upon in negligence decision making. Jason A. Cantone, If Only: An Empirical Examination Into How Counterfactual Thinking Can Help Predict Negligence Judgments (2008) (unpublished master's thesis, University of Nebraska at Lincoln) (on file with author).

252. See Reinert, 162 U. PA. L. REV., supra note 15, at 1775-83.

253. For a discussion of each of these examples into why judges might not have the necessary "judicial experience", see id. at $1775-83,76$.

254. Reinert explains that "the dearth of judicial experience may partly explain why, as the available empirical data suggest, plausibility pleading has not effectively filtered cases on the basis of merit." Id. at 1775 (citing Reinert, supra note 11). Not all of the authors of this Article are in agreement with Reinert's assessment.

255. TALEB, supra note 226, at 145; Daniel Kahneman has also noted that, "[P]aradoxically, it is easier to construct a coherent story when you know little, when there are fewer pieces to fit into the puzzle.” (DANiEl KAHNEMAN, Thinking FAST AND Slow 201 (2013)). 
person's confidence in it. ${ }^{256}$ Instead, we believe the next step is to acknowledge that narrative pleading practice pervaded federal complaints before Twombly and that research must address how to combat the potentially negative effects of such additional information, especially under a plausibility pleading standard that invites inconsistencies based upon a judge's own experiences.

\section{Study Limitations and Next Steps}

This study, like all empirical studies, faces limitations. We do not claim that Twombly and Iqbal had no effect on pleading practice. Preliminary research performed by the authors has found that narrative pleading practice has become more detailed after Iqbal in types of cases that are often the object of a motion to dismiss. ${ }^{257}$ Twombly and Iqbal might have changed pleading practice, but they did not kill notice pleading. It was already on its way out of practice.

256. See Richard J. Heuer, JR., Psychology of Intelligence Analysis (2006) (providing an overview of research on the need for information within the United States Intelligence Community). In addition, Paul Slovic conducted a study of expert handicappers for horse races and found that, as the experts were given additional information to base their decisions upon, accuracy remained stable, confidence rose sharply, and judgment policies exhibited more random error. He found that people "overestimate their weightings of minor cues and fail to recognize the extent to which their judgments can be predicted by only a few cues." Paul Slovic, Talk Presented at The Institute for Quantitative Research in Finance, Behavioral Problems of Adhering to a Decision Policy (May 1, 1973); see also Paul Slovic, Dan Fleissner \& W. Scott Bauman, Analyzing the Use of Information in Investment Decision Making: A Methodological Proposal, J. Bus., 45, $283-301$ (1972).

257. Preliminary findings involving a limited number of cases suggest that Twombly and Iqbal may have resulted in an increase in the quantity of facts pleaded, rather than a change in the nature of pleadings themselves. We compared the page length of complaints filed before Twombly and after Iqbal in several different types of cases. We found that in types of cases in which motions to dismiss for failure to state a claim are rare, the page length of complaints filed after Iqbal changed very little (page length in auto accident cases decreased by $10 \%$, from 6.9 pages to 6.2 pages (n.s. p $<0.520$ ), and in ERISA cases increased by $9 \%$, from 7.9 pages to 8.6 pages (n.s. $\mathrm{p}<0.521)$ ). However, page length of complaints filed after Iqbal increased greatly in employment discrimination cases in which motions to dismiss for failure to state a claim are more common (page length in employment discrimination cases increased by $74 \%$ from 9.3 pages to 16.3 pages $(\mathrm{p}<0.028)$. Page length in antitrust cases also increased by $30 \%$, from 29.3 pages to 38.1 pages, but was not statistically significant due to the small number of antitrust cases in the pilot sample (n.s. $p<0.109$ ). These findings are consistent with recent surveys that have asked attorneys for their impressions of the effects of Twombly and Iqbal on their litigation practices. In general these surveys find that plaintiffs' attorneys in cases likely to face a motion to dismiss are responding by adding facts to their complaints rather than choosing not to file cases that will be tested by the more demanding pleading standard. See LeE, supra note 135, and EMERY G. LeE III AND ThOMAS E. WiLlging, Fed. Judicial Ctr, AtTorney Satisfaction with the Federal Rules of Civil Procedure, REPORT TO THE Judicial CONFERENCE AdVISORY COMMITTEE ON Civil Rules 12 (Mar. 2010), available at http://www.fjc.gov/public/pdf.nsf/lookup/costciv2.pdf/\$file/costciv2.pdf (70\% of employment discrimination plaintiff attorneys indicated that the Supreme Court cases have affected their practice, and of those reporting an effect, $94 \%$ reporting that they now include more factual allegations in the complaint). 
One may argue that automobile accident cases are not representative of the diverse federal caseload, and we agree. Automobile accident cases present straightforward issues that arise in the federal courts. ${ }^{258}$ They are "relatively uncomplicated civil actions" 259 and the "archetypal notice pleading claim." 260 If notice pleading is not occurring in such simple, "archetypal" cases that have the benefit of Form 11, then it is also unlikely to be occurring in more complex cases that have no such guidance. It raises strong doubt that notice pleading was the dominant practice before Twombly or that complaints matched Form 11. Still, additional research should examine whether these findings generalize to other case types and whether the findings here accurately reflect the prevalence of narrative pleading before Twombly.

Form 11 also comes into question due to its use of words such as "negligently," which rides a thin line between factual allegation and legal conclusion. Miller states,

If it is considered a fact, courts should accept an allegation of negligent conduct as true and thereby confirm that Form 11 remains a sufficient model for this category of actions. On the other hand, if courts begin interpreting "negligently" as a legal conclusion, plaintiffs may have to channel tort law and specify the factual elements to qualify as a plausible claim. For example, plaintiffs may have to recite the precise actions taken or not taken by a defendant motorist that made his or her driving negligent. ${ }^{261}$

If courts take the former approach, the narrative pleading that existed before Twombly should still survive a motion to dismiss. If courts take the latter approach, pleadings that already exceeded Form 11 might need to include even more factual support. An argument could be made that litigants throughout history "played it safe" and always pled negligence complaints with greater specificity. Consequently, the shift in pleading practice pre- and post-Twombly might be more pronounced in other types of complaints, but it should not alter the finding that narrative pleading was common before Twombly.

258. Federal case weights assign motor vehicle accident cases a weight that is somewhat less than the typical federal case. Fed. Judicial Ctr., 2003-2004 District Court Case-Weighting Study, Appendix Y: Final Weights Material Presented to the Statistics Subcommittee, 2 tbl.4 (2005), available at http://www.fjc.gov/public/home.nsf/autoframe?openform\&url_l=/public/home.nsf/ inavgeneral?openpage\&url_r=/public/home.nsf/pages/665 (assigning a weight of 0.90 to motor vehicle accident cases, relative to a 1.00 weight of a typical federal case).

259. Miller, supra note 5, at 40.

260. Fairman, supra note 37, at 1047. Recall that Fairman's review of case law indicated that while non-notice pleading was common in more complex cases, notice pleading dominated in negligence cases. Id. at 1051 .

261. Miller, supra note 5, at 40-41. 
One reason why some researchers do not find major differences in the rate at which motions to dismiss are granted before Twombly and after Iqbal may be that this narrative pleading practice that includes additional facts became common before the Supreme Court cases were decided. If fact-rich complaints were common before Twombly, then comparison of grant rates of motions to dismiss before and after Twombly and Iqbal may show smaller than expected change, even if the articulated reasons for resolving motions challenging such pleadings could have differed significantly due to the heightened plausibility standard.

In 1986, academic debate greeted the Supreme Court's trilogy of summary judgment cases. ${ }^{262}$ In response, commentators criticized the Court for making it easier for defendants to be granted summary judgment. However, despite concerns after the decisions were announced, empirical research found that the likelihood that a case contained one or more summary judgment motions had already increased before the 1986 cases. ${ }^{263}$ The research here is a first step toward a comparable finding, though about attorney pleading practice. Despite much fervor over how the Supreme Court decisions would revolutionize federal practice, narrative pleading practice was already common before Twombly and lower courts had already started to adopt heightened pleading standards.

As we noted at the outset, it is important to distinguish pleading standards enforced by the courts from pleading practices adopted by attorneys in filing a complaint. This was a study of pleading practices, showing that the factual content of complaints before Twombly far exceeded the modest factual requirements of notice pleading. Pleading standards set a minimum requirement for pleading practices. Some may argue that, despite the extensive recitation of facts in complaints at the time of Twombly, the courts still measured pleadings by the notice pleading standard and the Form 11 template and ignored supplemental facts. However, as noted in Part III, Dodson found that, before Twombly, $25.3 \%$ of dismissed claims were dismissed because of insufficient facts ${ }^{264}$ and, as noted in Part $\mathrm{V}(\mathrm{C})$, that would be hard to do from a psychological perspective.

Our study indicates that narrative pleading was already common before Twombly. We believe this is partially a result of the Federal Rules amendments that encouraged providing information early in the litigation in attempts for more effective judicial case management. Moreover, we believe that the current Form 11 does not meaningfully aid litigants because judges have now come to expect more developed narrative pleading and the form

262. See Celotex Corp. v. Catrett, 477 U.S. 317 (1986); Anderson v. Liberty Lobby, Inc., 477 U.S. 242 (1986); and Matsushita Elec. Indus. Co. v. Zenith Radio Corp., 475 U.S. 574 (1986).

263. Joe S. Cecil, et al., A Quarter-Century of Summary Judgment Practice in Six Federal District Courts, 4 J. EMPIRICAL LEGAL STUD. 861, 861 (2007).

264. Dodson, supra note 23, at 98 tbl.3.3. 
might set an inadequate baseline for litigants. ${ }^{265}$ Additional research might find and address pleadings that follow the Form 11 format and explore if the surprisingly high percentage of narrative pleading negligence complaints mapped onto other case types as well. However, with the Judicial Conference recently recommending the abrogation of Rule 84 and the Forms, future research might better address whether such actions will further affect pleading practice.

\section{CONCLUSION}

Most critics of Twombly and Iqbal see those cases as a sharp departure from past notice pleading standards that caused changes in pleading practice. However, while we recognize the change between a notice and plausibility pleading standard and the concerns with plausibility pleading, recent research presents two factual oddities that cause us to question whether notice pleading practice, at least as intended by the drafters, was common before Twombly.

First, Twombly and Iqbal did not create a new era of narrative pleading. Instead, narrative pleading was already common before Twombly. Our studies demonstrate that pleadings rich with facts were common prior to Twombly and that pleading in complaints in federal automobile accident cases departed from the notice pleading practice expressed by the drafters of the Federal Rules in Form 11. Our studies show that, in 2006, in about nine out of ten cases, plaintiffs in straightforward automobile accident negligence cases alleged far more facts in the complaint than required by the notice pleading practice recommended by Form 11. Such supplemental facts offered more detailed information about the circumstances of the accident, the nature of the injuries, and the parties. Second, studies that distinguish between motions dismissed for insufficient facts and for insufficient legal grounds find many cases before Twombly dismissed for insufficient facts. These findings should come as a surprise to researchers who point to the decision in Twombly as the death of notice pleading.

Second, we believe that this fact-intense narrative pleading has arisen, in part, due to amendments to the Federal Rules that encourage greater judge involvement early in the case, as well as, early decisions about the possible narrowing of claims and the nature and breadth of discovery. These early judicial decisions, often taking place at an initial scheduling conference with the federal judge and attorneys, encourage plaintiffs to set forth a coherent and plausible narrative at the outset, with sufficient facts to provide a context

265. We recognize that a heightened standard, such as the plausibility standard, raises the bar for what a complaint must provide in order to survive such a motion. However, complaints already provided additional information before the Twombly and Iqbal decisions and judges might have become accustomed to such additional facts. This warrants additional research. 
to support the plaintiffs' claims. In reviewing such pleadings, federal judges rely on the narrative statements to make preliminary decisions about the strength of claims and the need for an amended complaint.

Twombly and Iqbal pose a number of problems, but the solution is not to return to the pleading practices the day before Twombly was decided. The uncertain manner in which judges might now rely on their judicial experience and common sense is a legitimate concern. Still, in suggesting a return to practices in accord with a notice pleading standard, critics should be clear about the exact pleading practices and standards that they find suitable and indicate when, if ever, the litigants and federal courts employed such practices, and how their proposed solutions will accommodate recent amendments to the civil rules.

It might still be too early to answer all of our questions. The Conley standard stood for more than fifty years under the Supreme Court's jurisprudence, though lower courts had formulated their own heightened pleading standards and litigants had engaged in narrative pleading practice before Twombly. It is possible that future ramifications from Twombly and Iqbal have not yet come to fruition. We are not just now "entering an age of storytelling pleading," ${ }^{266}$ but, in fact, are already years into this new age. ${ }^{267}$

266. GELBACH, supra note 17 , at 36.

267. See Fitzpatrick, supra note 115, at 1631 ("Despite the Supreme Court's best efforts prior to Twombly, these lower federal courts have been using heightened pleading standards for some time."). 